\title{
How depositional texture and diagenesis control petrophysical and elastic properties of samples from five North Sea chalk fields
}

\author{
Fabricius, Ida Lykke; Røgen, Birte; Gommesen, Lars
}

Published in:

Petroleum Geoscience

Link to article, DOI:

10.1144/1354-079306-707

Publication date:

2007

Link back to DTU Orbit

Citation (APA):

Fabricius, I. L., Røgen, B., \& Gommesen, L. (2007). How depositional texture and diagenesis control petrophysical and elastic properties of samples from five North Sea chalk fields. Petroleum Geoscience, 13, 8195. https://doi.org/10.1144/1354-079306-707

\section{General rights}

Copyright and moral rights for the publications made accessible in the public portal are retained by the authors and/or other copyright owners and it is a condition of accessing publications that users recognise and abide by the legal requirements associated with these rights.

- Users may download and print one copy of any publication from the public portal for the purpose of private study or research.

- You may not further distribute the material or use it for any profit-making activity or commercial gain

- You may freely distribute the URL identifying the publication in the public portal 


\title{
How depositional texture and diagenesis control petrophysical and elastic properties of samples from five North Sea chalk fields
}

\author{
Ida L. Fabricius ${ }^{1}$, Birte Røgen ${ }^{1}$ and Lars Gommesen ${ }^{1,2}$ \\ ${ }^{1}$ Institute of Environment and Resources, Technical University of Denmark, Bygningstorvet 115, DTU, \\ DK-2800 Kgs. Lyngby, Denmark. (e-mail: iff@er.dtu.dk.) \\ ${ }^{2}$ Present address: Marsk Olie og Gas A/S, Copenhagen, Denmark.
}

\begin{abstract}
Chalk samples from Dan, Tyra, South Arne, Valhall and Ekofisk fields were collected from hydrocarbon-bearing intervals in the Cretaceous Tor and Palaeogene Ekofisk formations in the central North Sea. The samples were compared with respect to stable isotope ratios, lithotype, texture, porosity, permeability, capillary entry pressure, as well as the dynamic elastic Biot's coefficient and Poisson's ratio. The depositional texture and present grain-size distribution were quantified by petrographic image analysis. Oxygen isotope ratio and Biot's coefficient were used as indicators of cementation.

Porosity varies more than 20 porosity units within each hydrocarbon field and is controlled by three parameters: (1) sorting as expressed by Dunham texture, so that mudstones tend to have highest porosity and packstones the lowest; (2) sorting of the carbonate mud, where a mixture of clay-size chalk particles and silicates tend to reduce porosity; and (3) by pore-filling cementation. The relative significance of these parameters varies with field and formation. The presence of chalk clasts as an indicator of re-deposited chalk seems to have no relationship to porosity. Permeability and capillary entry pressure depend on porosity and mineral content as expressed in specific surface. Prediction of permeability and capillary entry pressure may be aided by information on carbonate content or on Poisson's ratio.
\end{abstract}

KEYWORDS: Chalk, texture, diagenesis, North Sea

\section{INTRODUCTION}

In the central part of the North Sea Basin, the upper Cretaceous and Palaeogene Chalk Group hosts hydrocarbon reservoirs (Megson \& Hardman 2001). The productivity of these reservoirs is highly influenced by fracturing, but reservoir properties of the chalk itself vary considerably (Andersen 1995). The present study investigates how porosity, permeability and capillary entry pressure reflect depositional texture and diagenesis in unfractured samples from five hydrocarbonbearing chalk fields. The five fields are located in the Central North Sea area of regional overpressure (Japsen 1998). The fields form a southeast-northwest transect and vary with respect to burial depth and overpressure (Fig. 1, Table 1). In addition, dynamic elastic parameters, such as Poisson's ratio (for predicting permeability and capillary entry pressure) and Biot's coefficient (useful in interpreting diagenesis of chalk) will be introduced.

\section{Depositional texture}

The mode of chalk deposition was discussed by Kennedy $(1980,1987)$. Based on cores from several chalk fields he found that allochthonous chalk tends to have the best reservoir properties. These results have been applied widely (Hatton 1986; Taylor \& Lapré 1987; Brasher \& Vagle 1996) but were contested by the results of Maliva \& Dickson (1992), who studied chalk from the Eldfisk Field and found that mode of deposition has little influence on porosity. They rather found that content of non-carbonates is significant, although the content of non-carbonates may indicate variations in microfacies, as fine-grained silica presumably represents diagenetically reprecipitated biogenic silica. Fabricius \& Borre (2007) studied chalk from the Gorm and Tyra fields, North Sea, and found that the presence of cemented microfossils and pore-filling silicates causes local variations in porosity of chalk. In accordance with Maliva \& Dickson (1992), Røgen \& Fabricius (2002) found that for a given porosity, content of clay and silica has significant influence on permeability and capillary entry pressure in chalk.

Crabtree et al. (1996) standardized chalk description and grouped the chalk into 18 lithotypes based on a macroscopic equivalent to the texture classification of Dunham (1962). They found that in the Chalk Group, mud-supported mudstone and wackestone textures prevail, whereas grain-supported mud-rich packstones are rare and grainstones extremely rare. Røgen et al. (1999) reviewed the chalk lithotypes defined by Crabtree et al. (1996), and recommended the use of Dunham's classification in its original form. They grouped the 18 lithotypes into four lithotype sets:

- Lithotype Set 1: mudstones (mud-supported with less than $10 \%$ grains larger than $20 \mu \mathrm{m}$ in thin section;

- Lithotype Set 2: pebbly chalk, comprising micro-mudstones and micro-wackestones; 

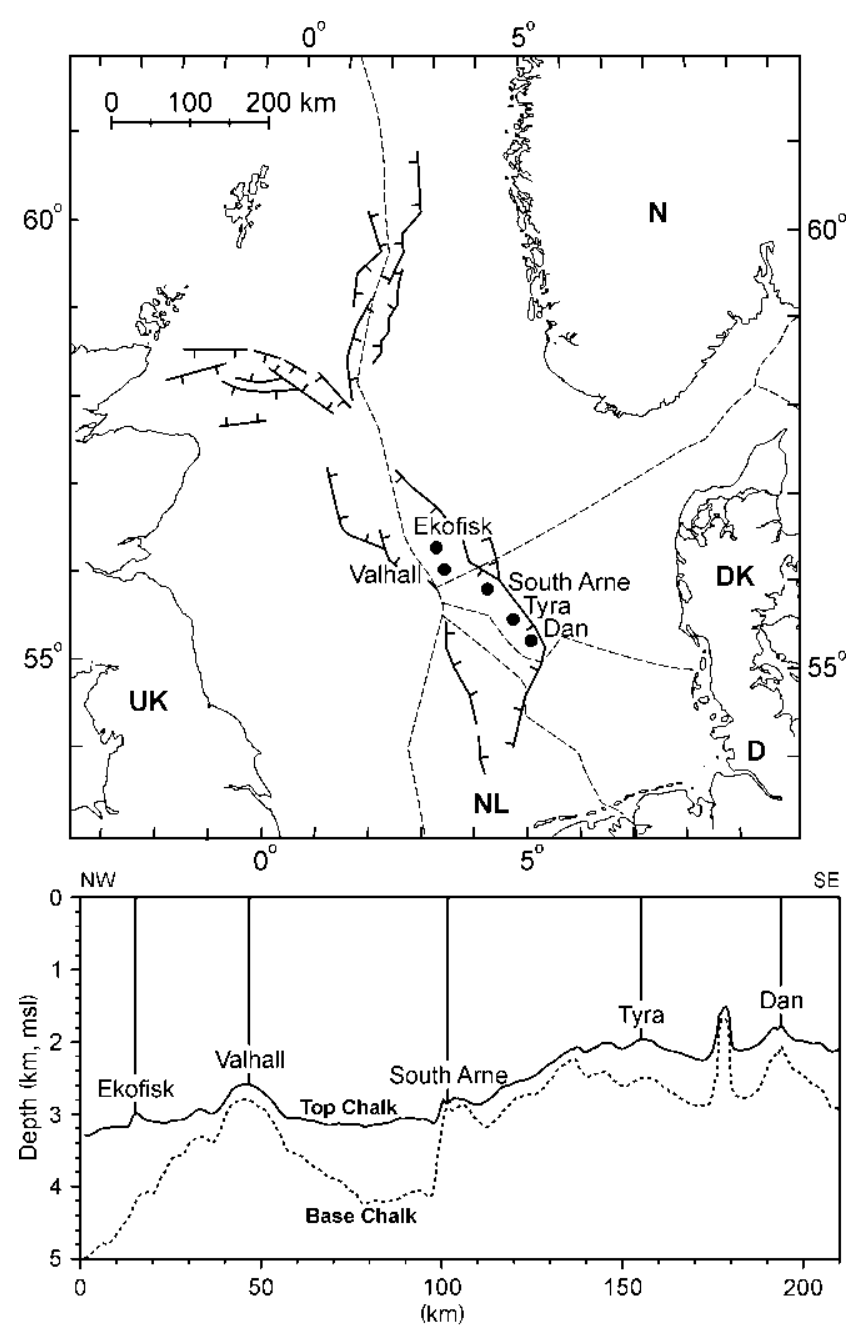

Fig. 1. Samples were collected from the reservoir zone of five North Sea chalk fields: from the Tor and Ekofisk formations of the Ekofisk Field, from the Tor Formation of the Valhall Field, from the Tor Formation of the South Arne Field, from the Ekofisk Formation of the Tyra Field, and mainly from the Tor Formation of the Dan Field. Structural elements on the map are adapted from Ziegler (1990). The cross-section was compiled by Ole V. Vejbæk. The depth scale is in $\mathrm{km}$ below mean sea-level (msl).

Table 1. Sampled chalk fields

\begin{tabular}{llcc}
\hline Field & \multicolumn{1}{c}{$\begin{array}{c}\text { Formation and } \\
\text { no. of samples }\end{array}$} & $\begin{array}{c}\text { Type of } \\
\text { hydrocarbon }\end{array}$ & $\begin{array}{c}\text { Regional overpressure } \\
\text { (MPa) }\end{array}$ \\
\hline Dan $^{\mathrm{a}}$ & Ekofisk (1), Tor (60) & oil and gas & 6.4 \\
Tyra $^{\mathrm{b}}$ & Ekofisk (21) & gas & 9.1 \\
South Arne $^{\mathrm{c}}$ & Tor (29) & oil & 15.4 \\
Valhall $^{\mathrm{d}}$ & Tor and Hod? (9) & oil & 19.5 \\
Ekofisk $^{\mathrm{e}}$ & Ekofisk (22), Tor (28) & oil and gas & 16.7 \\
\hline
\end{tabular}

${ }^{a}$ Andersen (1995), Kristensen et al. (1995), Scholle et al. (1998), Damholt \& Surlyk (2004).

${ }^{\mathrm{b}}$ Doyle \& Conlin (1990).

cJapsen (1998), Mackertich \& Goulding (1999).

${ }^{d}$ Caillet et al. (1997), Farmer \& Barkved (1999).

${ }^{\mathrm{e}}$ Brewster et al. (1986), Caillet et al. (1997).

- Lithotype Set 3: wackestones - mud-supported with more than $10 \%$ microfossil- and bioclast-grains, larger than $20 \mu \mathrm{m}$ in thin section;

- Lithotype Set 4: packstones and argillaceous chalk with more than $30 \%$ clay and silica.

\section{Diagenesis}

The progress of diagenesis in chalk has been addressed widely from the ratio of stable oxygen isotopes. Using a large number of chalk samples from the Danish North Sea and the Danish sub-basin, Jørgensen (1987) studied stable isotope ratios for carbon, $\delta^{13} \mathrm{C}$ and oxygen, $\delta^{18} \mathrm{O}$. He found $\delta^{13} \mathrm{C}$ in the range $+0.50 \%$ to $+3.00 \%$ o relative to the Pee Dee Belemnite [PDB], corresponding to marine biogenic calcite, whereas he found $\delta^{18} \mathrm{O}$ in the range $-0.50 \%$ to $-7.50 \%$ [PDB], decreasing with depth of burial in a given well and decreasing with porosity. He concluded that the data indicate an equilibration between pore water and carbonate involving dissolution and re-precipitation processes taking place in a diagenetically closed system. In agreement with this conclusion, Maliva et al. (1991) modelled stable isotope data from the Eldfisk Field, North Sea and found that in chalk with porosity above 35\%, diagenesis was dominated by dissolution and re-precipitation without porosity loss, as reflected in whole-rock $\delta^{18} \mathrm{O}$ of $-4.1 \%$ to $-4.7 \%$ [PDB]. Maliva \& Dickson (1992) found only little evidence of intergranular pressure dissolution and found stylolites to be the major source of cement.

Diagenesis of chalk may also be reflected in the dynamic elastic properties. Fabricius (2003) related diagenesis of deep sea and North Sea chalk to elastic P-wave modulus, $M(\mathrm{GPa})$ (Mavko et al. 1998):

$$
M=\rho v_{P}^{2}
$$

where $\rho\left(\mathrm{g} \mathrm{cm}^{-3}\right)$ is bulk density and $v_{P}\left(\mathrm{~km} \mathrm{~s}^{-1}\right)$ is P-wave velocity; and Gommesen et al. (2007) pointed to the significance of Biot's coefficient. For a given porosity, Biot's coefficient, $a$, is an indicator of pore stiffness and may be supposed to decline with increasing cementation. $\alpha$ may be calculated from dynamic elastic data for the mineral phase and for the dry sample (Mavko et al. 1998):

$$
a=\left(1-\frac{K_{d y y}}{K_{o}}\right)
$$

The bulk modulus of the mineral phase, $K_{o}$ is close to $71 \mathrm{GPa}$ for calcite, and the dynamic elastic bulk modulus for the dry sample, $K_{d r y}(\mathrm{GPa})$ may be calculated from dry bulk density, $\rho_{d}\left(\mathrm{~g} \mathrm{~cm}^{-3}\right), v_{P}\left(\mathrm{~km} \mathrm{~s}^{-1}\right)$ of the dry sample, and S-wave velocity, $v_{S}\left(\mathrm{~km} \mathrm{~s}^{-1}\right)$ of the dry sample:

$$
K_{d r y}=\rho_{d}\left(v_{P}^{2}-\frac{4}{3} v_{S}^{2}\right)
$$

\section{Petrophysical properties}

The petrophysical properties included in the present study are porosity, permeability and capillary entry pressure. Prediction of permeability from porosity of chalk is commonly done by correlation of core data from a specific formation, preferably in a specific field. Capillary pressure in chalk is generally predicted by the equivalent radius method (EQR, e.g. Vejbæk et al. 2005). This method was developed by Engstrøm (1995). He noted that the Leverett (1940) model, among others, was unsuited to match chalk capillary curves because the assumptions do not hold: constant irreducible water saturation, $S_{\text {wir }}$, is not observed. For each of the Ekofisk and Tor formations, Engstrøm normalized non-wetting phase saturation, $\left(1-S_{w}\right)$, to $\left(1-S_{\text {wir }}\right)$, and capillary pressure, $P_{c}$, to capillary entry pressure, $P_{c e}$, and established relationships between the normalized data.

In chalk, permeability and capillary entry pressure is controlled largely by porosity and specific surface (Mortensen et al. 


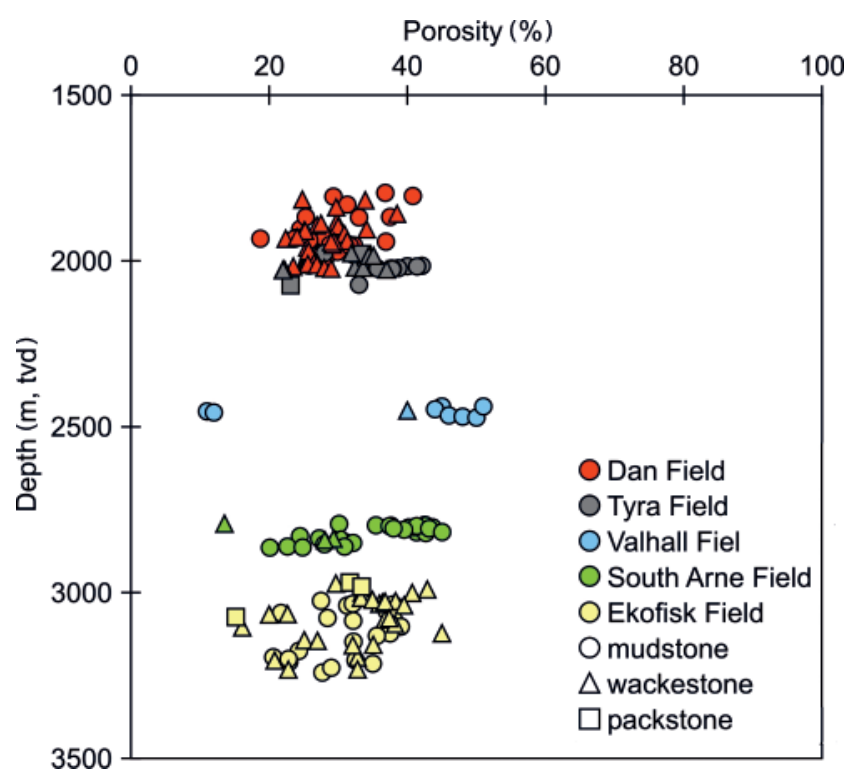

Fig. 2. Most samples have mudstone or wackestone texture, whereas single samples have packstone texture. The five fields are located at different vertical depths below sea-level (tvd) (see Fig 1). Porosity varies more than 20 porosity units irrespective of burial.
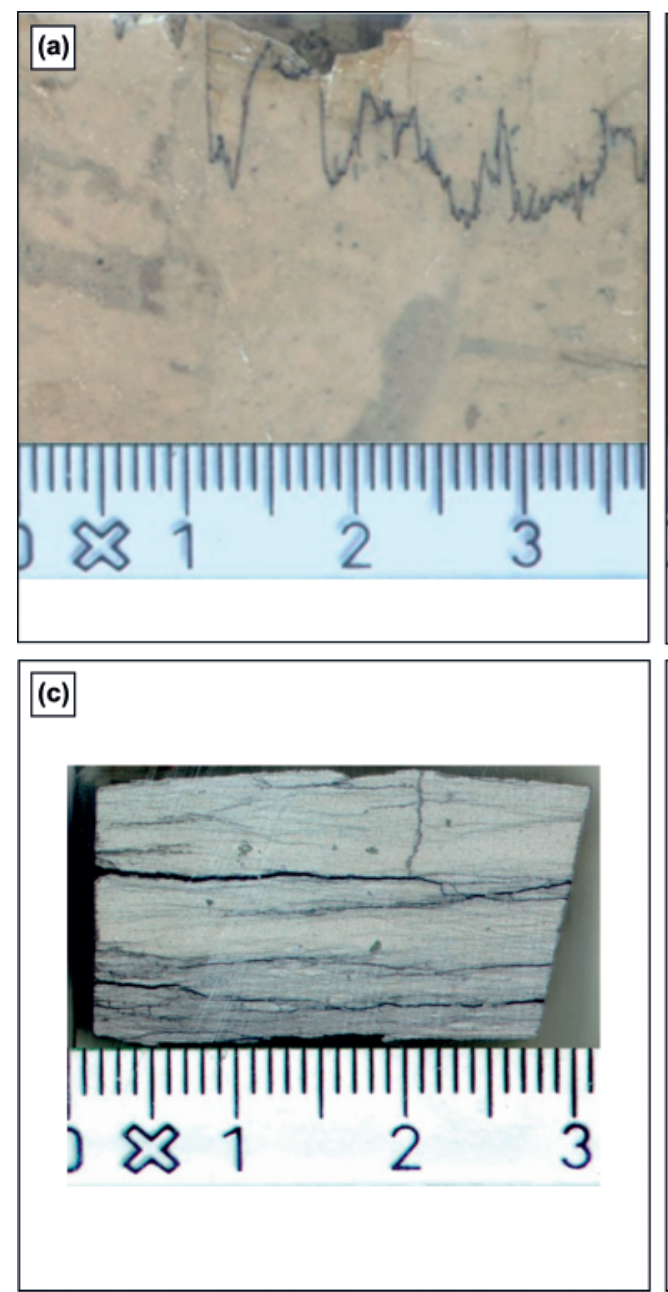

1998; Røgen \& Fabricius 2002). For homogeneous chalk they confirmed that the Kozeny (1927) equation can be derived without empirical constants:

$$
\kappa_{k}=c \phi^{3} / s^{2}
$$

$\kappa_{k}$ is Klinkenberg corrected permeability (mD) (Klinkenberg 1941), while $c$ is a (non-empirical) function of porosity whose value is close to 0.25 for chalk in a large porosity range; with the present choice of units it must be multiplied by $10^{-3} \cdot \phi$ is porosity $(\%)$, and $s$ is specific surface with respect to bulk volume $\left(\mathrm{m}^{2} \mathrm{~cm}^{-3}\right) . s$ is calculated from dry density, $\rho_{d}$ $\left(\mathrm{g} \mathrm{cm}^{-3}\right)$, and specific surface per unit mass, $S\left(\mathrm{~m}^{2} \mathrm{~g}^{-1}\right)$, measured by the method of Brunauer et al. (1938):

$$
s=S \rho_{d}
$$

In accordance with Leverett (1940), Røgen \& Fabricius (2002) found that capillary entry pressure is proportional to the ratio between specific surface and porosity:

$$
P_{c e} \approx s / \phi
$$
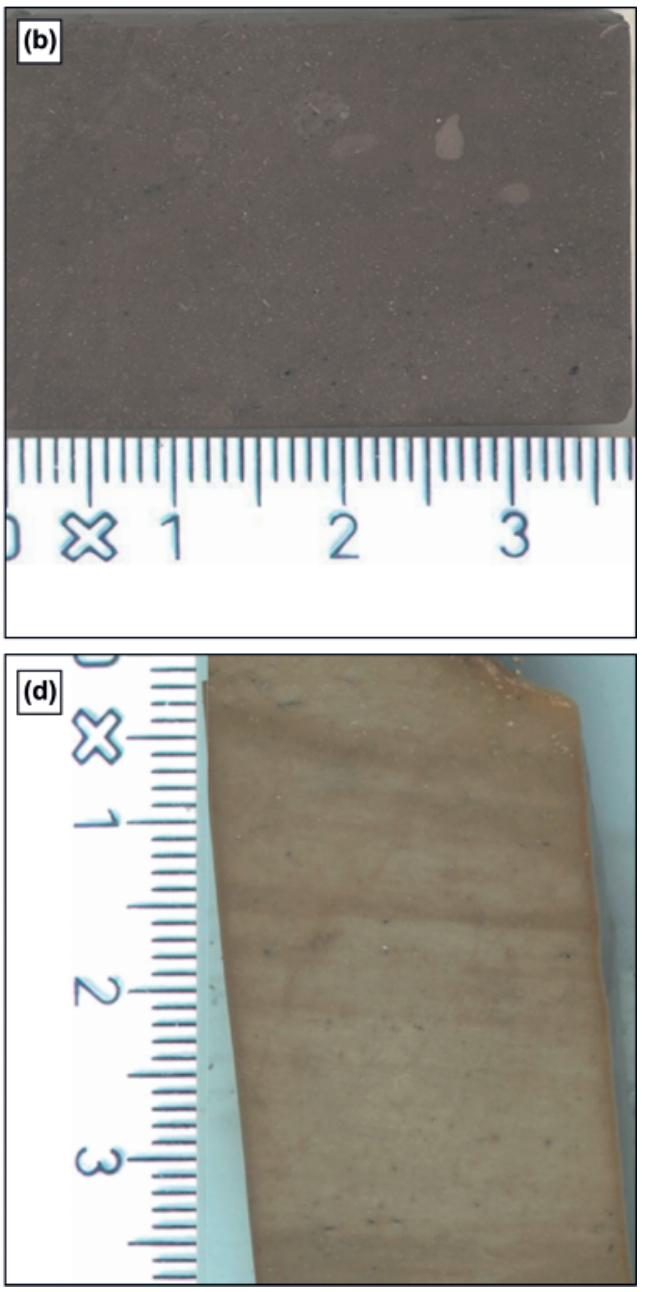

Fig. 3. Epoxy-impregnated and polished samples. (a) Deformed burrowed massive chalk mudstone from the Tor Formation of the Dan Field (Lithotype Set 1,98\% carbonate, $28 \%$ porosity). (b) Deformed pebbly chalk wackestone from the Tor Formation of the South Arne Field (Lithotype Set 2, 96\% carbonate, 43\% porosity). (c) Laminated argillaceous chalk packstone from the Ekofisk Formation of the Ekofisk Field (Lithotype Set 4, 46\% carbonate, 15\% porosity). (d) Laminated chalk wackestone from the Tor Formation of the Dan Field (Lithotype Set 3, $99 \%$ carbonate, $30 \%$ porosity). The apparent lamination in this sample may be due to differential epoxy-impregnation along fractures. 

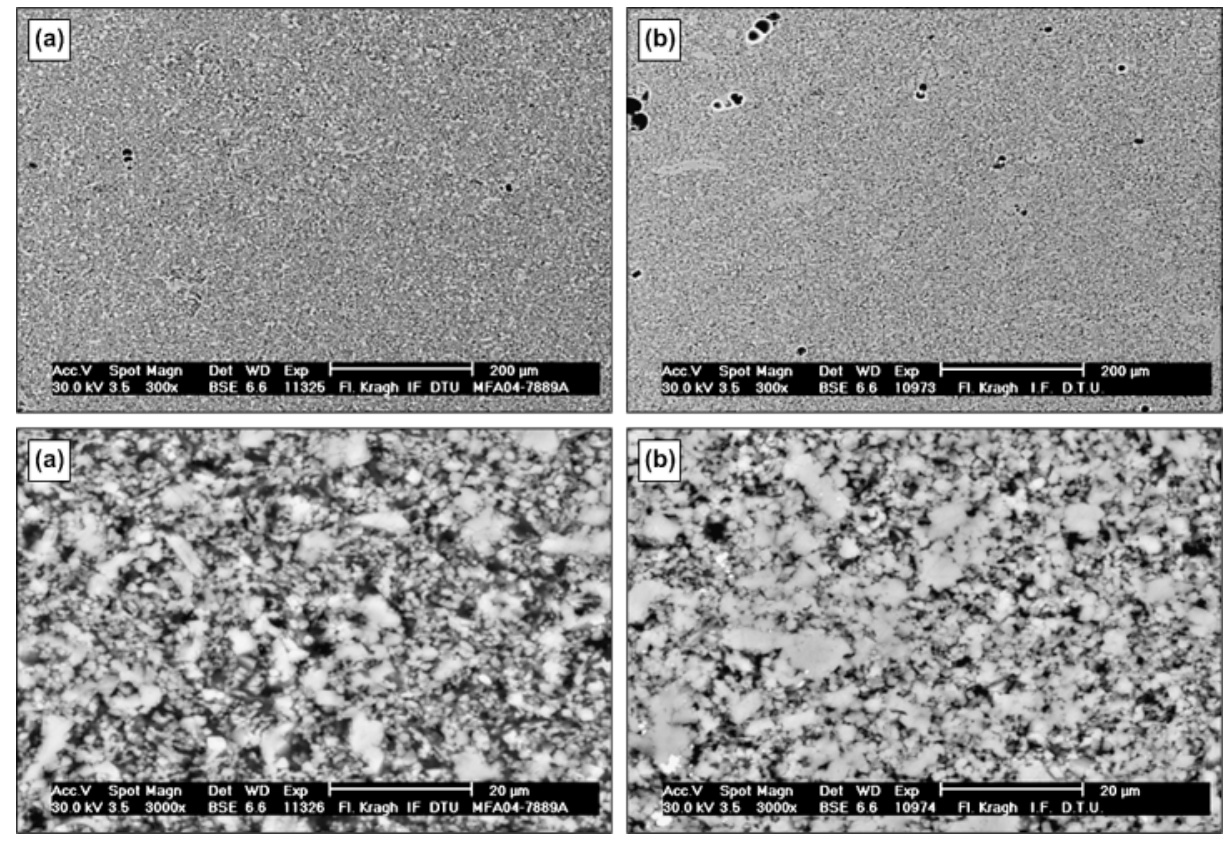

Fig. 4. Backscatter electron micrographs in two magnifications from the Dan Field, Tor Formation illustrating the role of pore-filling cementation. Both samples are burrowed massive chalk mudstone (Lithotype Set 1) with mudstone microtexture and a carbonate content of $98 \%$. Whereas sample (a) has a porosity of $38 \%$ and Biot's coefficient of 0.97 , sample (b) is more cemented as indicated by a lower porosity $(25 \%)$ and a smaller Biot's coefficient of 0.80 .
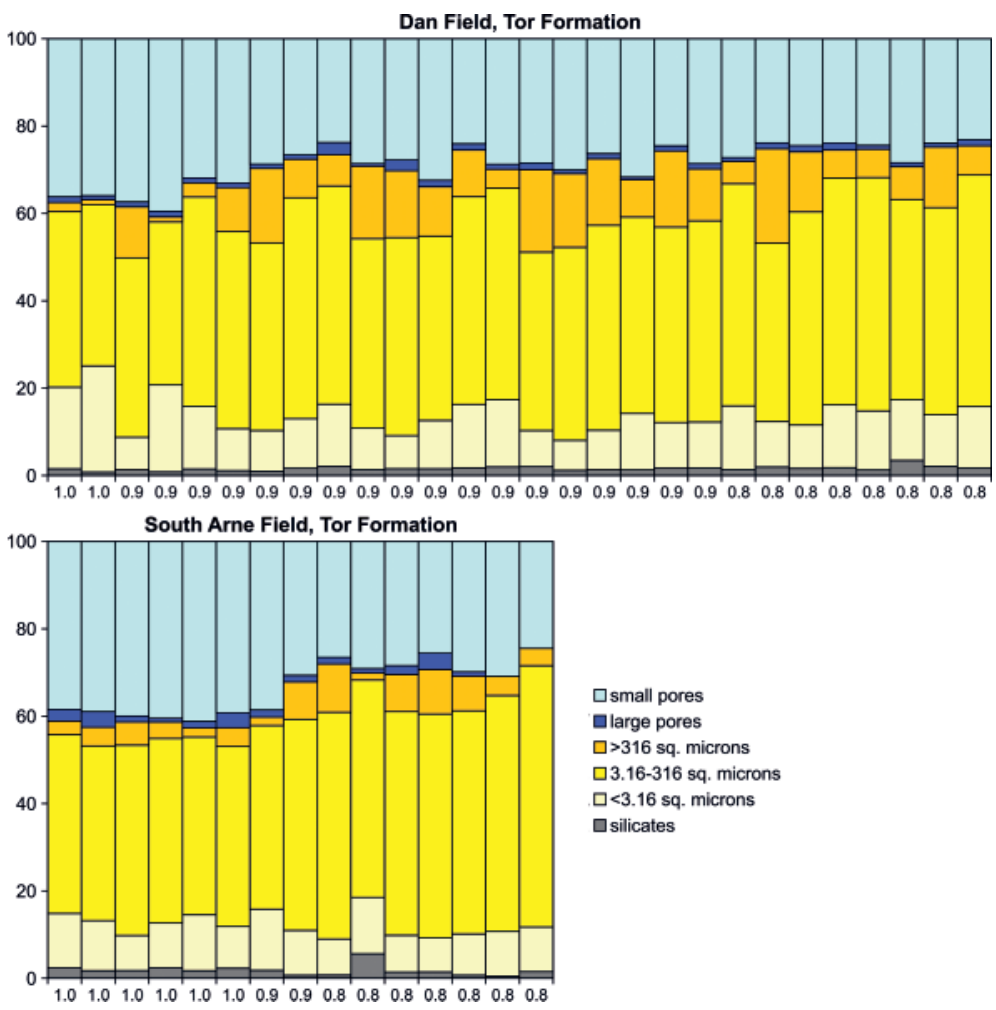

Fig. 5. Bulk composition as measured by petrographic image analysis of samples from the Tor Formation of the Dan and South Arne fields. The samples are sorted according to Biot's coefficient ( $x$-axis), which decreases with increasing pore stiffness relative to sample stiffness. In both fields porosity decreases primarily as Biot's coefficient decreases, indicating that porosity is controlled primarily by pore-filling cementation. Content of microfossils $\left(>316 \mu \mathrm{m}^{2}\right)$ gives a second-order porosity-reducing effect. Where the apparent fine-grained part of the matrix is only $10 \%$, it is probably largely an artefact due to the two-dimensional method of measurement.

$$
v=\left(v_{P}^{2}-2 v_{S}^{2}\right) /\left(2\left(v_{P}^{2}-v_{S}^{2}\right)\right)
$$

Porosity is normally available from well logs, whereas the specific surface can be assessed only indirectly. The specific surface of chalk is controlled primarily by clay and quartz due to the high smoothness of the calcite crystals constituting the building blocks of the carbonate fossils (Røgen \& Fabricius 2002). Clay may be assessed from the radioactive signal, but quartz is not radioactive. Because $v_{P}$ and $v_{S}$ are unequally influenced by mineralogy and pore structure (e.g. Mavko et al. 1998), porosity together with $v_{P} / v_{S}$ ratio may give information on the content of quartz and clay and thereby permeability and capillary entry pressure. The $v_{P} / v_{S}$ ratio is reflected in the dynamic elastic parameter, $v$, Poisson's ratio (e.g. Mavko et al. 1998):
In the present study, dry Poisson's ratio was calculated from ultrasonic laboratory data, but it may be assessed from sonic Pand S-wave logging data via fluid substitution (Gassmann 1951).

\section{DATA AND EXPERIMENTAL PROCEDURE}

Samples for the present study were taken from the hydrocarbon-bearing zones of five chalk fields representing the Tor and Ekofisk formations (Table 1). Petrophysical data were 

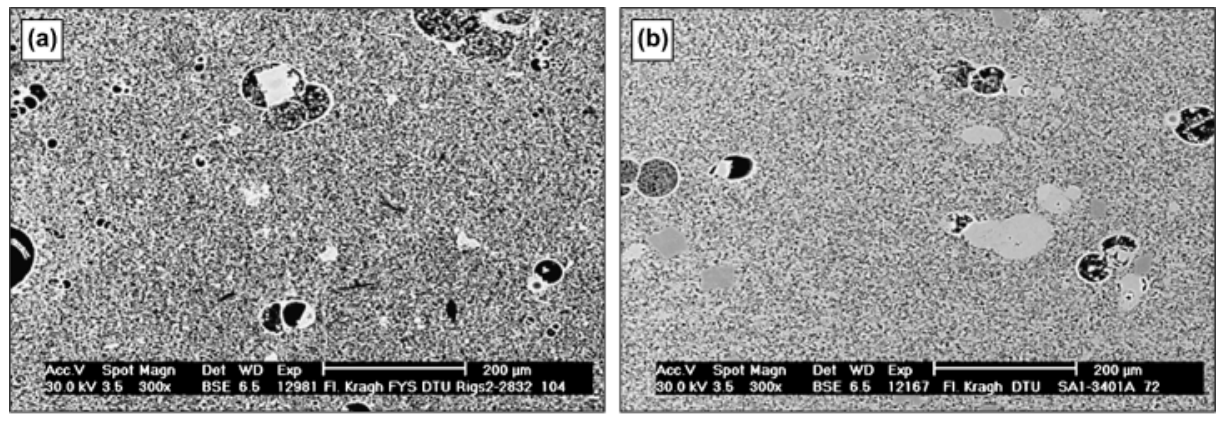

Fig. 6. Backscatter electron

micrographs in two magnifications from the South Arne Field, Tor Formation illustrating the role of pore-filling cementation. (a) Deformed pebbly chalk wackestone (Lithotype Set 2) with wackestone microtexture and a
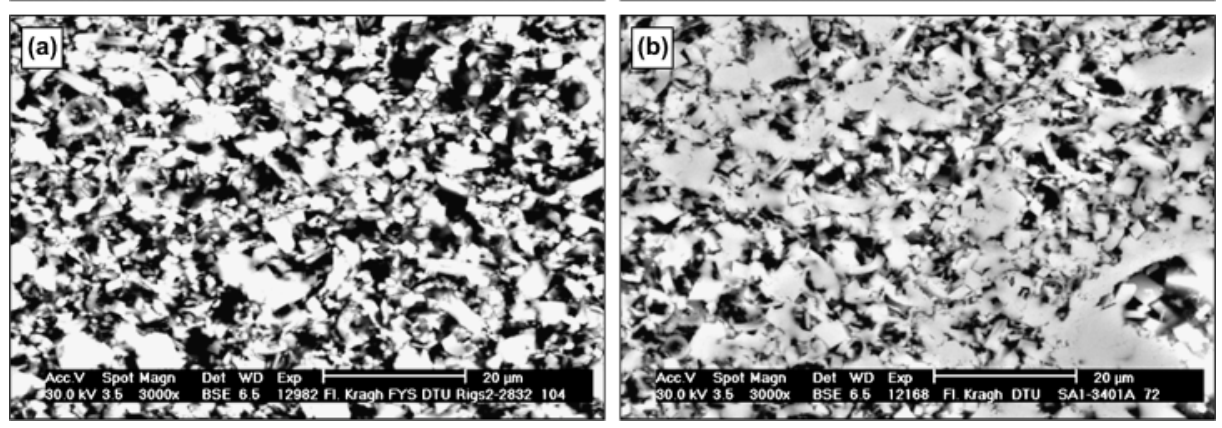
carbonate content of $97 \%$. Porosity is $43 \%$ and Biot's coefficient of 0.98 . (b) More cemented, as indicated by a lower porosity $(29 \%)$ and a smaller Biot's coefficient of 0.84 . It is a deformed burrowed massive chalk wackestone (Lithotype 3) with wackestone microtexture and a carbonate content of $98 \%$. The sample contains authigenic dolomite (grey rhombs) and authigenic kaolinite (small particles within intrafossil porosity to the left in the upper image).
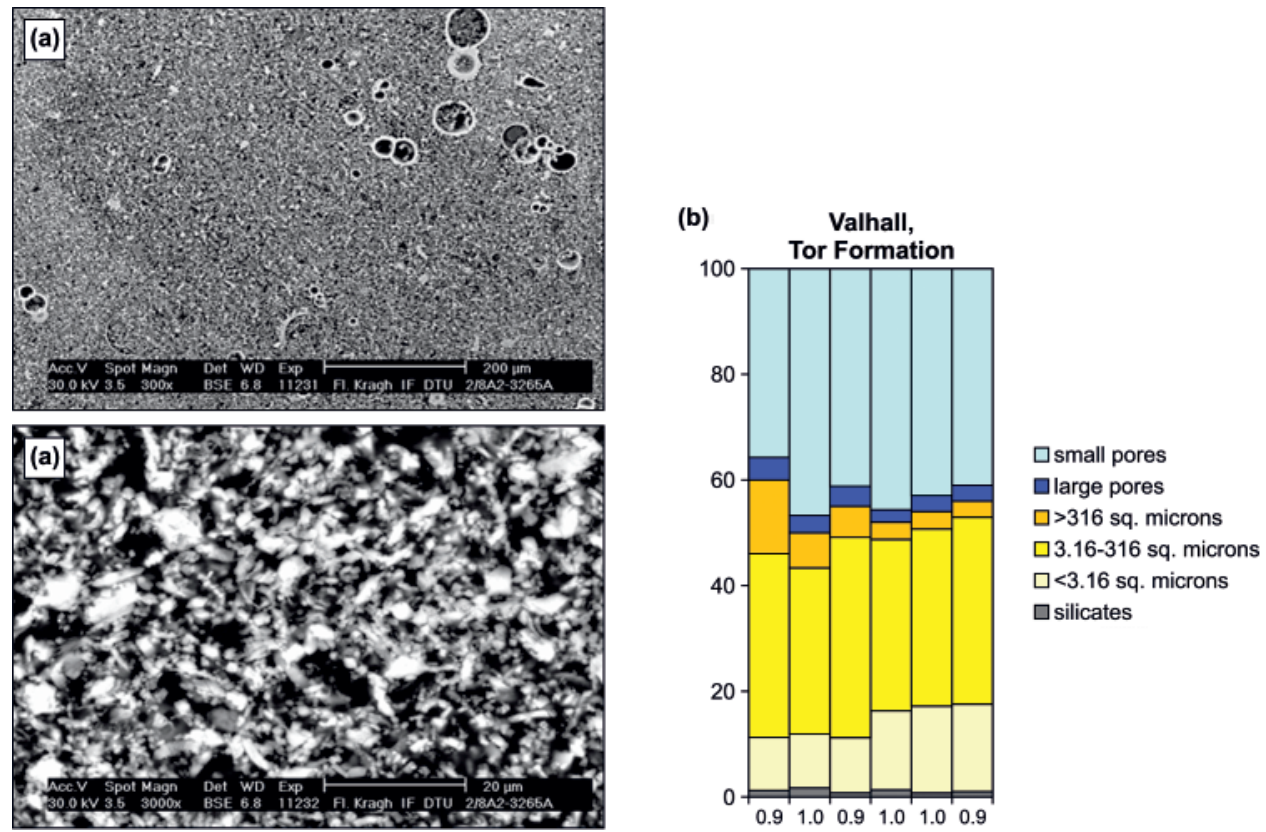

Fig. 7. (a) Backscatter electron micrographs in two magnifications from a highly porous sample from the Valhall Field, Tor Formation. The sample is a burrowed massive chalk mudstone (Lithotype Set 1) with mudstone microtexture and a carbonate content of $97 \%$. Porosity is $50 \%$ and Biot's coefficient is 0.97. (b) Bulk composition as measured by petrographic image analysis of samples from the Tor Formation of the Valhall Field. The samples are sorted according to the content of fine-grained calcite $\left(<3.16 \mu \mathrm{m}^{2}\right)$. Two low-porosity samples are not included because they are heavily cemented and not suitable for analysis of grain-size distribution.

provided by field operators and samples were collected adjacent to 170 plug holes where data on He-porosity and gas permeability, as well as mercury capillary pressure curves, were already available. He-porosity is normally measured with an uncertainty of less than 0.1 porosity units, gas permeability with an uncertainty of around 5\%, although at low permeability $(0.1 \mathrm{mD})$ the uncertainty becomes as high as $20-25 \%$. The capillary entry pressure was determined from capillary pressure curves by using the EQR method of Engstrøm (1995). By this procedure, the uncertainty on capillary entry pressure is assessed to be less than 20 psi. Røgen \& Fabricius (2002) discussed the mineralogical composition of the samples. Røgen et al. (2005) discussed the acoustic properties of the South Arne Field samples.

For the present work, lithotype was described on a slabbed, polished surface of 127 samples, and microtexture assessed from thin sections of all samples. The microtexture was confirmed quantitatively from grain-size distribution as measured by image analyses of backscatter electron micrographs, where information from two magnifications was combined (Røgen et al. 2001). By this method grain-size distribution is defined from cross-sectional area in a two-dimensional plane perpendicular to bedding. Samples with a height and width of approximately $1 \mathrm{~cm}$ were impregnated with epoxy and polished 

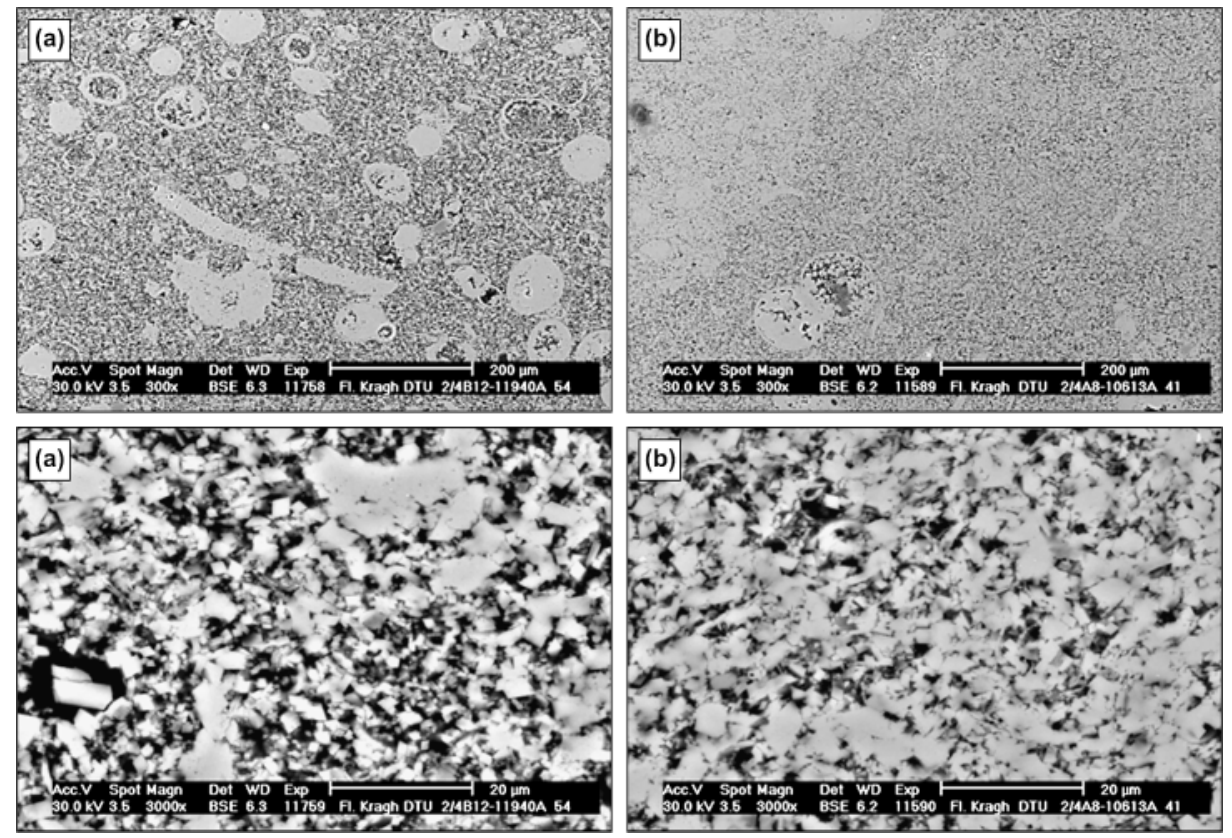

Fig. 8. Backscatter electron micrographs in two magnifications from the Ekofisk Field, Tor Formation illustrating pebbly chalk (Lithotype Set 2) with wackestone vs. mudstone microtexture. (a) Massive pebbly chalk wackestone with wackestone microtexture and a carbonate content of $94 \%$. Porosity is $25 \%$ and Biot's coefficient is 0.85 . (b) Massive pebbly chalk wackestone with mudstone microtexture and a carbonate content of $98 \%$. Porosity is $23 \%$ and Biot's coefficient is 0.78 .

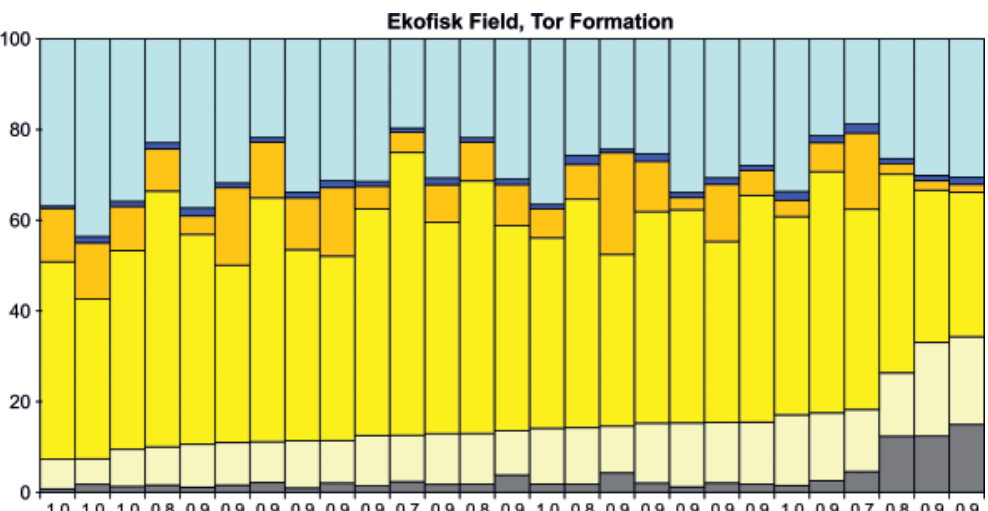
Ekofisk Field, Ekofisk Formation

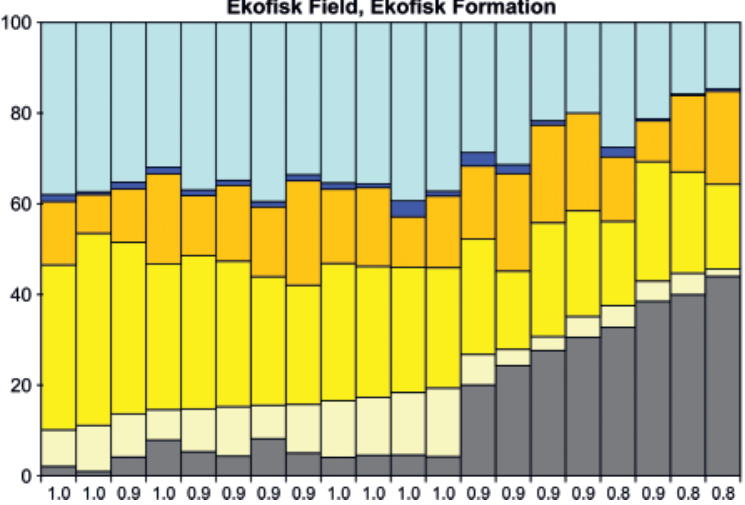

口small pores

alarge pores a>316 sq. microns प3.16-316 sq. microns $\square<3.16$ sq. microns 口silicates

Fig. 9. Bulk composition as measured by petrographic image analysis of samples from the Tor and Ekofisk formations of the Ekofisk Field. The samples are sorted according to the content of fine-grained carbonates $\left(<3.16 \mu \mathrm{m}^{2}\right)$ and silicates. In both formations, porosity decreases primarily as the fine-grained component increases. In the Tor Formation the second-order porosity-reducing effect seems to be cementation, as indicated by the low Biot's coefficient ( $x$-axis). In the Ekofisk Formation, the content of microfossils $\left(>316 \mu \mathrm{m}^{2}\right)$ gives a second-order porosity-reducing effect.

before imaging with a Philips XL20 scanning electron microscope by using the backscatter electron detector. A standard imaging procedure was followed for each sample. This includes an overview image for each sample to check for inhomogeneities in sample or preparation. Four image fields were chosen along the centreline in the vertical direction, with a spacing of $2 \mathrm{~mm}$. Each image field is represented by two images. One image at high magnification $(60 \times 80 \mu \mathrm{m})$, representing only chalk matrix, insoluble residue and matrix porosity. The second image is a concentric image at a magnification ten times lower $(600 \times 800 \mu \mathrm{m})$, showing microfossils, chalk clasts and shell debris, as well as large porosity (intraparticular and moldic porosity), but not resolving the matrix. From a combination of information from each of the magnifications and under the assumption of a homogeneous matrix, information corresponding to 100 images of the high magnification were obtained at each image field of the lower magnification.

Ultrasonic P-wave and S-wave velocities were measured at $5 \mathrm{MHz}$ by using a pulse transmission technique on dry unconfined samples. The samples were thus not at in situ stress, but samples from the South Arne Field were also measured at hydrostatic pressure equivalent to in situ stress, and the ultrasonic velocities obtained by the two methods were found to differ by less than the experimental uncertainty. By error 

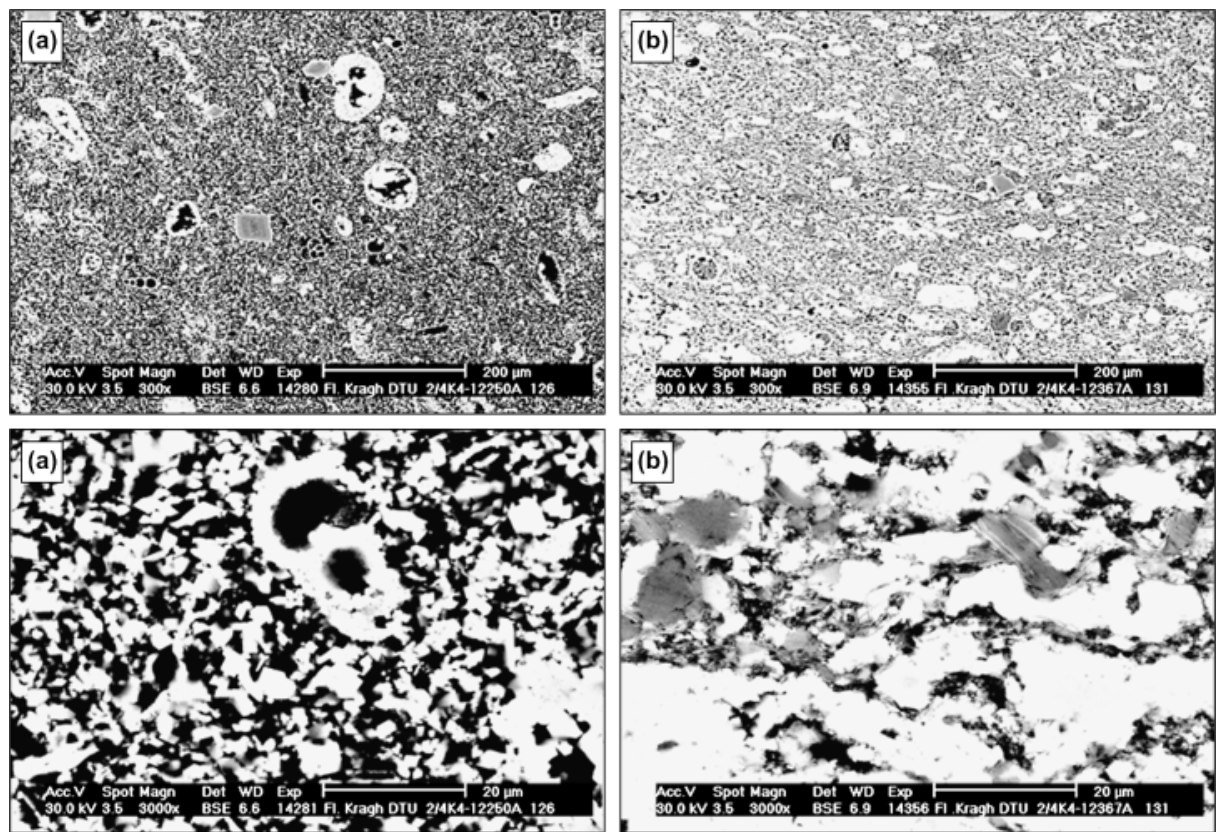

Fig. 10. Backscatter electron

micrographs in two magnifications from the Ekofisk Field, Ekofisk Formation, illustrating the role of high compared with low content of fine-grained mud $\left(<3.16 \mu \mathrm{m}^{2}\right)$. (a) Burrowed massive chalk wackestone (Lithotype Set 3) with wackestone microtexture and a carbonate content of $97 \%$. Porosity is $40 \%$ and Biot's coefficient is 0.96. (b) Laminated chalk packstone (Lithotype Set 4) with packstone microtexture and a carbonate content of $46 \%$. Porosity is $15 \%$ and Biot's coefficient is 0.84 . It contains detrital silicates including large kaolinitic clasts.

propagation, standard deviation of $\mathrm{P}$-wave and $\mathrm{S}$-wave velocity is estimated to be less than $0.1 \mathrm{~km} \mathrm{~s}^{-1}$ and $0.05 \mathrm{~km} \mathrm{~s}^{-1}$, respectively. The dry density is measured with an accuracy of $2 \%$, so, by error propagation, the resulting error on the Biot coefficient becomes less than $16 \%$, and the resulting error on Poisson's ratio becomes less than $22 \%$.

Stable oxygen and carbon isotope ratios of bulk samples were measured by a standard method (Hoefs 2004). The experimental error on isotope ratios is estimated to be below $0.1 \%$. Carbonate content was measured by adding $0.5 \mathrm{M}$ hydrochloric acid to the powdered sample and subsequent titration by $0.5 \mathrm{M}$ sodium hydroxide solution and is accurate to $\pm 0.2 \%$

\section{RESULTS}

Of the 170 studied samples, 126 are from the Tor Formation, whereas 44 are from the Ekofisk Formation (Table 1). With respect to microtexture, most samples are mudstones or wackestones although some are packstones. For each field, porosity varies more than 20 porosity units (pu), although burial depth varies from less than two to more than three kilometres (Fig. 2). With respect to lithotype, burrowed massive chalk mudstone is the most frequent (36 samples, Fig. 3a). Some 23 samples were found to be pebbly, i.e. to contain chalk clasts an indicator of reworking (Fig. 3b). Six samples were described as laminated. Of these, two packstones with less than $80 \%$ calcium carbonate were laminated as a result of horizontal alignment of clay and flattened wackestone-filled burrows (Fig. 3c), whereas the apparent lamination in the remaining four samples (one mudstone, two wackestones and one packstone) was visible only in oil-stained samples and may be a result of local permeability enhancement caused by low-angle fractures forming a steep angle with the polished surface (Fig. 3d).

Quantification of microtexture by image analysis indicates that the textural control on porosity varies according to the field. In some fields primary texture is the main control on porosity. In other fields porosity is controlled primarily by diagenesis as quantified by Biot's coefficient (Figs 4-10). In samples from the Tor Formation of the Dan and South Arne fields, the porosity seems to be controlled primarily by porefilling cementation as reflected in the decreasing Biot's coefficient, whereas content of microfossils gives a secondorder porosity-reducing effect (Figs 4-6). In samples from the Tor Formation of the Valhall Field porosity seems to be controlled primarily by the sorting of the mud-matrix, whereas the second-order control is provided by the content of microfossils (Fig. 7). In samples from the Tor Formation of the Ekofisk Field porosity seems to be controlled primarily by the sorting of the mud-matrix, while the second-order effect is pore-filling cementation as reflected in the decreasing Biot's coefficient (Figs 8-9). In the Ekofisk Formation of the Tyra and Ekofisk fields porosity seems to be controlled primarily by the sorting of the mud-matrix, while the second-order control is the content of microfossils (Figs 9-10; for BSE images $(30 \times 40 \mu \mathrm{m}$ and $300 \times 400 \mu \mathrm{m})$ and histogram of the Tyra samples, refer to Røgen et al. 2001). For the Tor Formation, high-porosity samples are mainly from the South Arne and Valhall fields, and low-porosity samples mainly from the Dan Field. For the Ekofisk Formation, the porosity distribution of samples from the Tyra and Ekofisk fields is similar (Fig. 11).

Depositional texture is related to porosity in general terms: Lithotype Sets 1 and 2 with mudstone microtexture dominate the most porous samples, whereas samples of the chalk clast-bearing Lithotype Set 2 may have high or low porosity (Fig. 11). Lithotype Sets 3 and 2 with wackestone microtexture are frequent for intermediate porosities, whereas samples with the poorly sorted Lithotype Set 4, including samples with packstone microtexture and samples rich in silicates, tend to have low porosity (Fig. 11).

With respect to stable isotope ratios, it is found that samples from the Dan, Tyra, South Arne and Ekofisk fields show a large variation in oxygen isotopes and a small variation with respect to carbon isotopes, whereas the opposite is seen for samples from the Valhall Field (Fig. 12). The pattern in Dan, Tyra, South Arne and Ekofisk corresponds to the closed system diagenesis as discussed by Jørgensen (1987). $\delta^{13} \mathrm{C}$ and $\delta^{18} \mathrm{O}$ are correlated positively, and a relatively large change in $\delta^{18} \mathrm{O}$ corresponds with a smaller change in $\delta^{13} \mathrm{C}$. This pattern will arise when during recrystallization oxygen equilibrates with dissolved bicarbonate and water, causing a lowering in $\delta^{18} \mathrm{O}$ due to the relative abundance of water, while carbon 


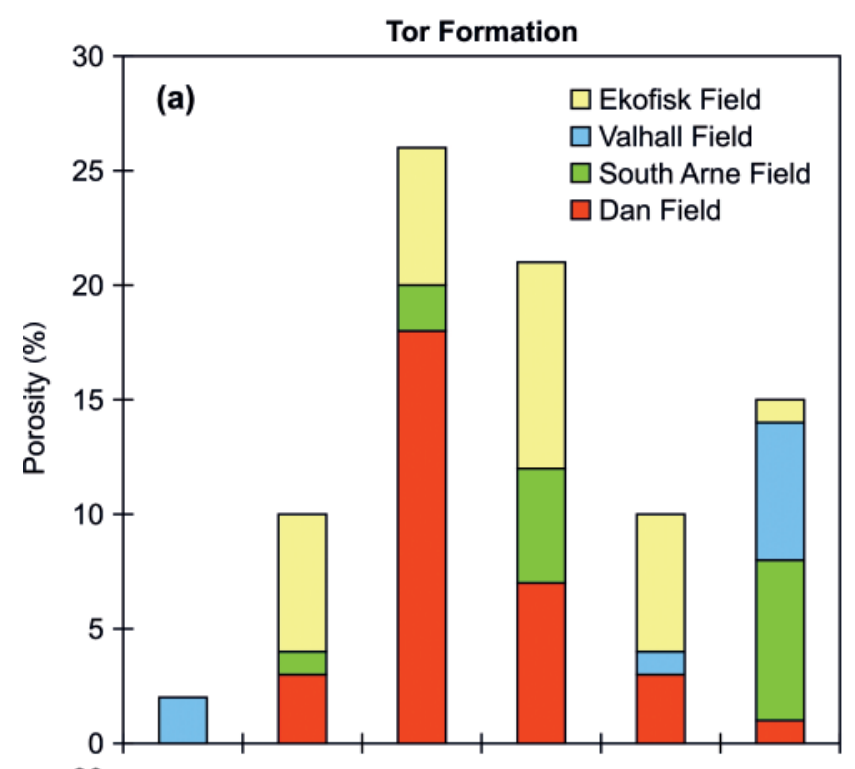

Porosity
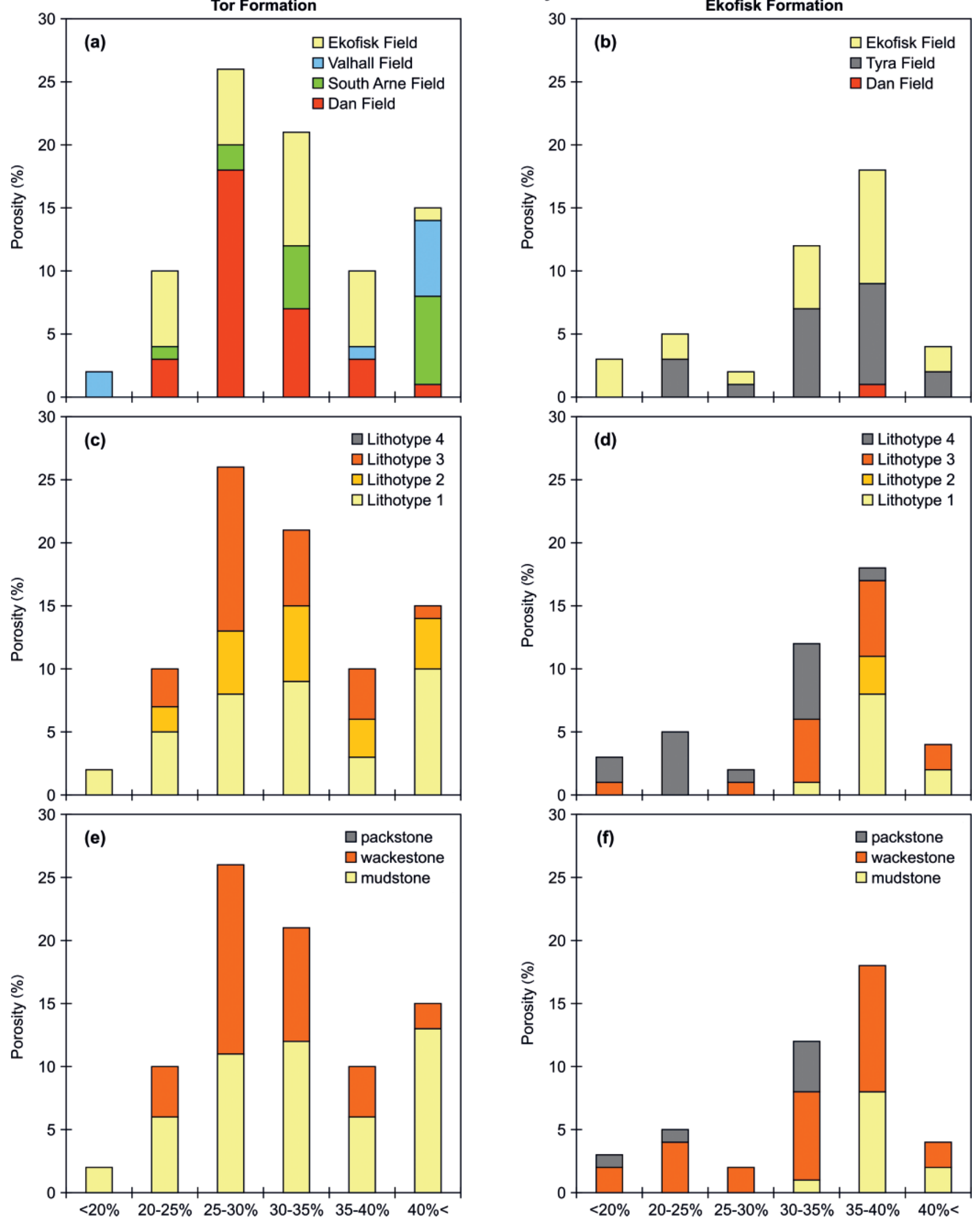

Fig. 11. Porosity histograms for the Tor and Ekofisk formations: $(\mathbf{a}, \mathbf{b})$ high-porosity samples mainly from the South Arne and Valhall fields, whereas low-porosity samples mainly from the Dan Field; (c-f) Lithotype Sets 1 and 2 with mudstone microtexture dominate the most porous samples. Samples of the pebbly Lithotype Set 2 may have high or low porosity. Lithotype Sets 3 and 2 with wackestone microtexture dominate for intermediate porosities. Lithotype Set 4 represents low porosity. It includes poorly sorted samples with packstone microtexture and samples rich in silicates. 

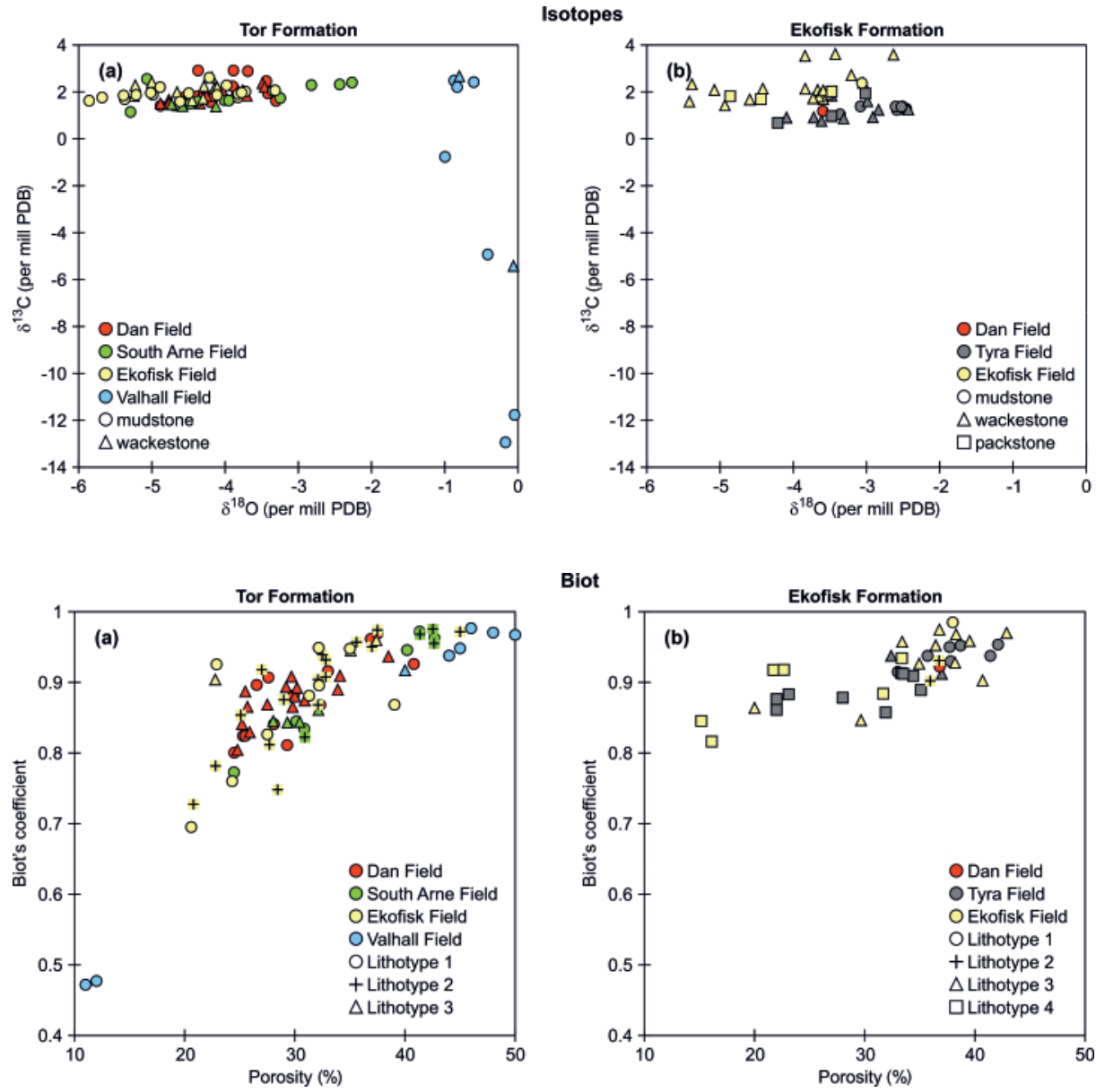

Biot
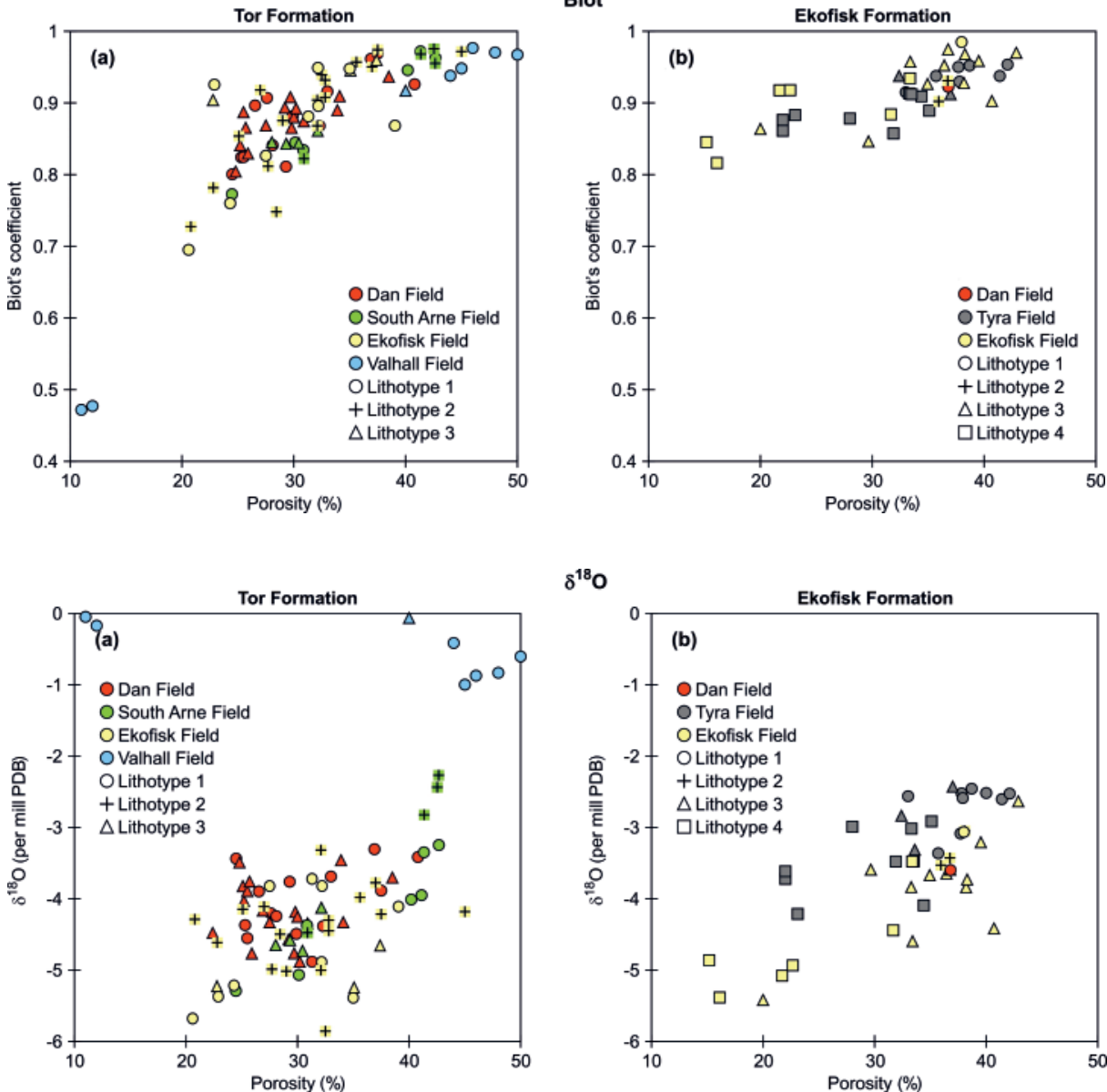

Fig. 12. Carbon and oxygen stable isotope ratios for samples from the (a) Tor and (b) Ekofisk formations, annotated with respect to fields and microtexture. Stable oxygen isotope ratio varies around 3\%o for samples from the Dan, Tyra, South Arne and Ekofisk fields. Stable carbon isotope ratio varies considerably for samples from the Valhall Field. $\delta^{18} \mathrm{O}$

Fig. 13. Biot's coefficient versus porosity for samples from the (a) Tor and (b) Ekofisk formations, annotated with respect to field and lithotype set. For porosity below $30 \%$, samples from the Tor Formation have a relatively low Biot's coefficient

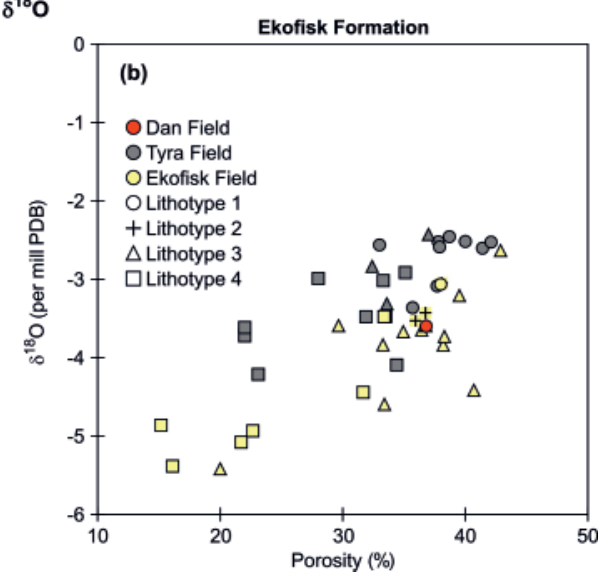

Fig. 14. Ratio of stable oxygen isotopes versus porosity for samples from the (a) Tor and (b) Ekofisk formations, annotated with respect to fields and lithotype set. For samples from the Tor Formation of the South Arne Field and Ekofisk Formation of the Tyra and Ekofisk fields, the stable oxygen isotope ratio and porosity are related positively, whereas a considerable scatter is seen for samples from the Tor Formation of the Dan and Ekofisk Fields. This indicates that cementation is not the only porosity-reducing factor. equilibrates only with the relatively sparse dissolved bicarbonate. The anomalous pattern shown by the Valhall samples may be explained by the introduction of hydrocarbons into the Valhall Field at relatively shallow burial. Jensenius \& Munksgaard (1989) found $\delta^{13} \mathrm{C}$ as low as $-16.5 \%$ [PDB] in calcite cement in the fractures in the chalk of the East Rosa Field, probably as a consequence of the presence of partly biodegraded isotopically light hydrocarbons.

In accordance with Jensenius \& Munksgaard (1989), the presence of partly degraded hydrocarbons during recrystallization may cause a low $\delta^{13} \mathrm{C}$ in the Valhall samples, while the limited amount of porewater causes $\delta^{18} \mathrm{O}$ to remain high.

\section{DISCUSSION}

Lamination, re-deposited chalk, texture and porosity

Whereas lamination in some samples is easy to recognize it is more equivocal in other cases (Fig. 3). The apparent lamination seen in Figure 3d is interpreted to reflect low-angle fractures; however, other researchers have interpreted presumably similar structures differently. Scholle et al. (1998) found metre-scale lithologic cycles in Maastrichtian (Tor Formation) chalk of the Dan Field. The cycles comprise a porous, laminated (?), largely non-stylolitic part capped by a hard, 3-8 pu less porous, bioturbated, stylolitic chalk with concentrations of bioclasts. 


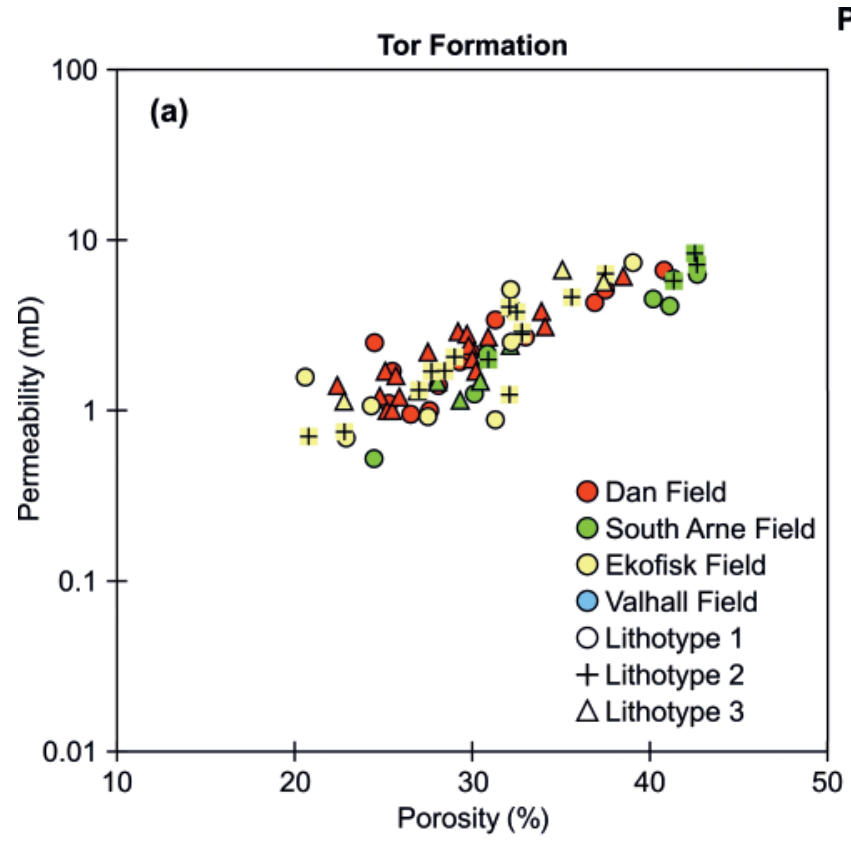

Permeability
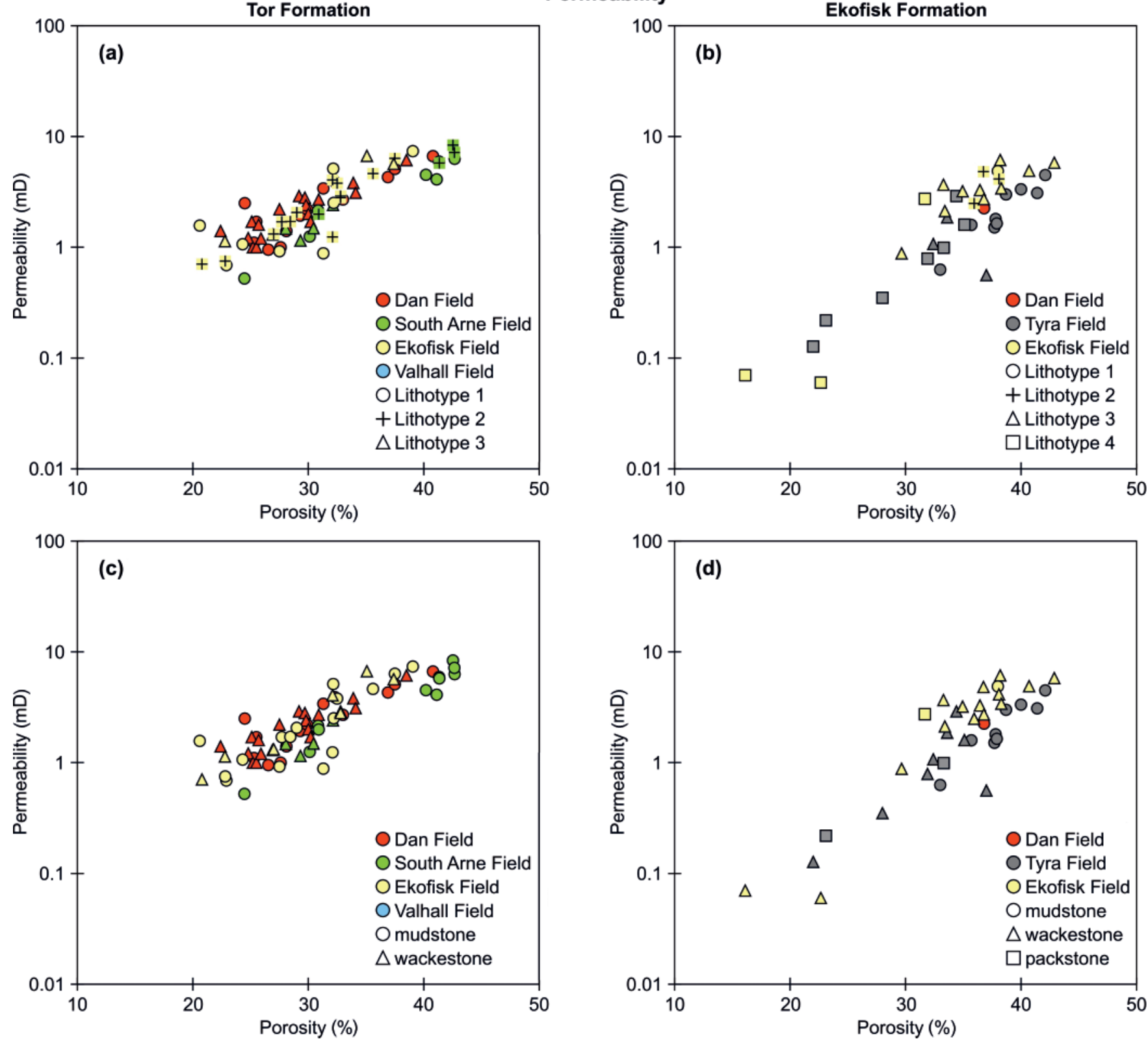

Fig. 15. Permeability versus porosity for samples from the Tor and Ekofisk formations: $(\mathbf{a}, \mathbf{b})$ annotated with respect to fields and lithotype set; (c, d) annotated with respect to fields and microtexture. Neither lithotype nor microtexture has a clear influence on the permeability-porosity trend.

They interpreted winnowing processes to have caused the lamination together with periods of rapid deposition as evidenced by the presence of escape burrows. Damholt \& Surlyk (2004) interpreted the biogenic structures as central parts of Zoophycos burrows rather than escape burrows. They interpreted the apparent lamination as resulting from low-density turbidity currents, or pelagic rain of pelleted coccoliths under anoxic conditions so as to preserve lamination. Both publications present only rather ambiguous petrographic evidence for the lamination which is visible by oil staining.

According to the results of this study (Fig. 11), pebbly chalk, which is probably re-deposited, may have high porosity in accordance with the results of Kennedy (1987), but pebbly chalk is not always porous and high porosity may be found in chalk with no clear indication of re-deposition. When $\delta^{13} \mathrm{C}-$ $\delta^{18} \mathrm{O}$ trends of the Tor and Ekofisk formations are compared (Fig. 12), it can be seen that most Ekofisk Formation samples from the Ekofisk Field fall close to the trend of the Tor Formation, whereas samples from the Ekofisk Formation of the Tyra Field fall on a trend shifted to c. 1\%o lower $\delta^{13} \mathrm{C}$. The shift seen in Tyra samples may reflect a shift in primary composition of isotopes at the transition from the Maastrichtian into the Danian. This interpretation is in accordance with Scholle \& Arthur (1980). They compiled data from pelagic limestones in the Circum-Atlantic-western Tethyan region and found a drop in $\delta^{13} \mathrm{C}$ of $c .1 \%$ at the transition from the Maastrichtian into the Danian, interpreted as a reflection of probable faunal and floral changes. The absence of a similar pattern for the samples from the Ekofisk Field may be a consequence of an abundance of reworked Cretaceous sediment in the Ekofisk Formation of the Ekofisk Field (Perch-Nielsen 1979). According to this interpretation of carbon isotope data, the Ekofisk Formation samples of the Ekofisk Field may be generally reworked, although samples 

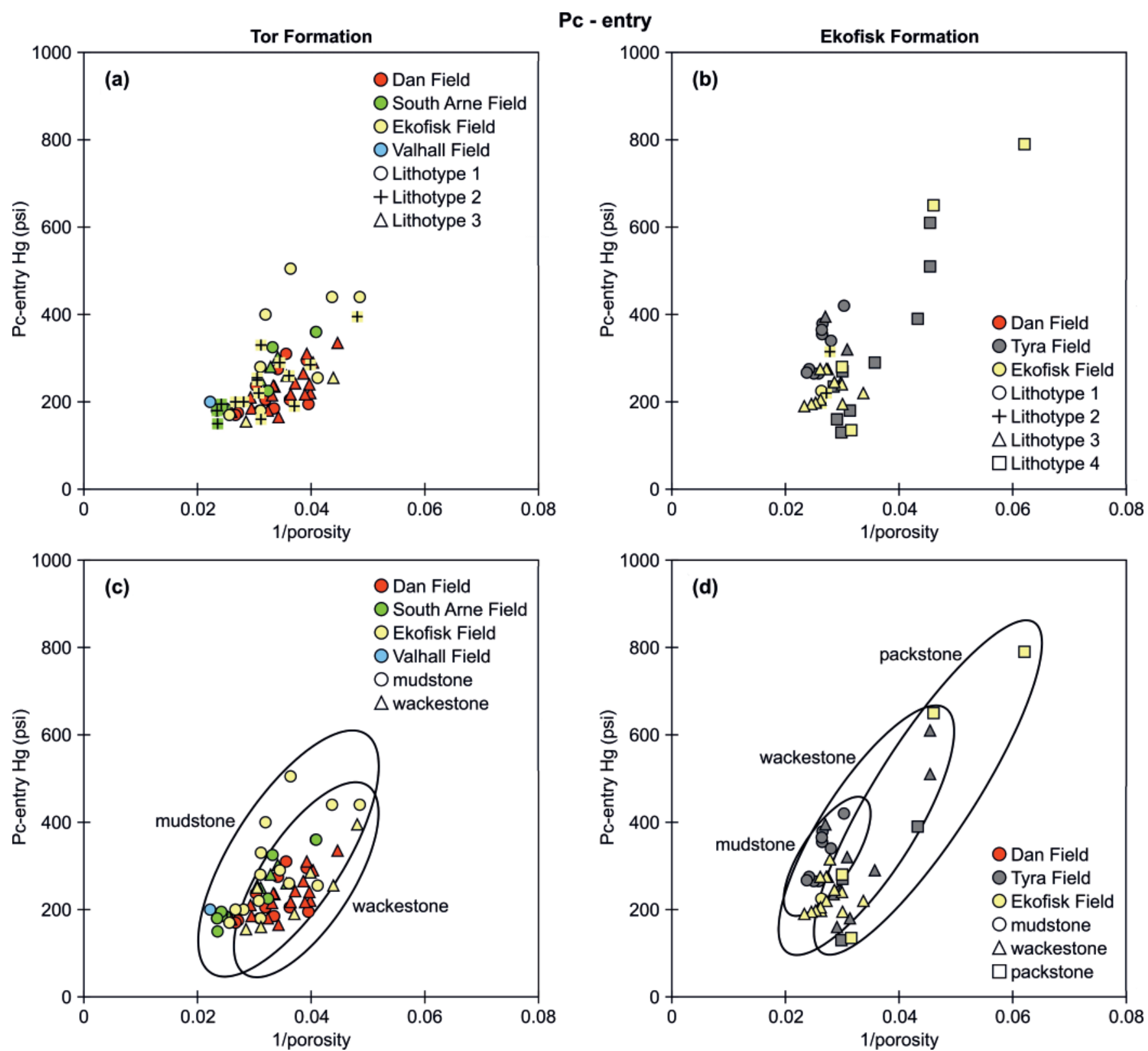

Fig. 16. Air-mercury capillary entry pressure versus inverse porosity for samples from the Tor and Ekofisk formations: (a, b) annotated with respect to fields and lithotype set; (c, d) annotated with respect to fields and microtexture. Lithotype and microtexture influence the capillary entry pressure-porosity relationship for both formations. A given capillary entry pressure corresponds to a low inverse porosity for well-sorted mudstones and to a high inverse porosity for poorly sorted packstones.

are not all clast-bearing. However, the porosity distribution of these samples is similar to the porosity distribution of the Tyra Field samples, where neither lithotype nor isotope ratios indicates reworking (Figs 11, 12). In accordance with Maliva \& Dickson (1992), the current data do not indicate a direct relationship between porosity and possible reworking of chalk.

High porosity chalk tends to have mudstone texture and packstones tend to have relatively low porosity (Fig. 11), but as seen from the petrographic data (Figs 4-10) - not only classical Dunham texture, but also sorting in the mud matrix, have a control on porosity. Accordingly, Lind \& Grøn (1996) found grain-size distribution in the matrix to be the controlling factor on porosity in a few samples from the Tor Formation in the Tyra Field and, in accordance with Maliva \& Dickson
(1992), fine-grained silicates were found to have significant porosity-reducing effect, especially in the Ekofisk Formation (Fig. 9).

Primary depositional control on porosity may thus be:

- relative proportion of calcareous microfossils relative to nannofossils resulting in mudstones, wackestones or packstones;

- relative proportion of siliceous fossils giving rise to secondary very fine-grained silica;

- admixtures of allochthonous clay;

- winnowing processes removing the most fine-grained parts of the matrix.

Winnowing may result from re-deposition by mass flow or be due to traction currents. 


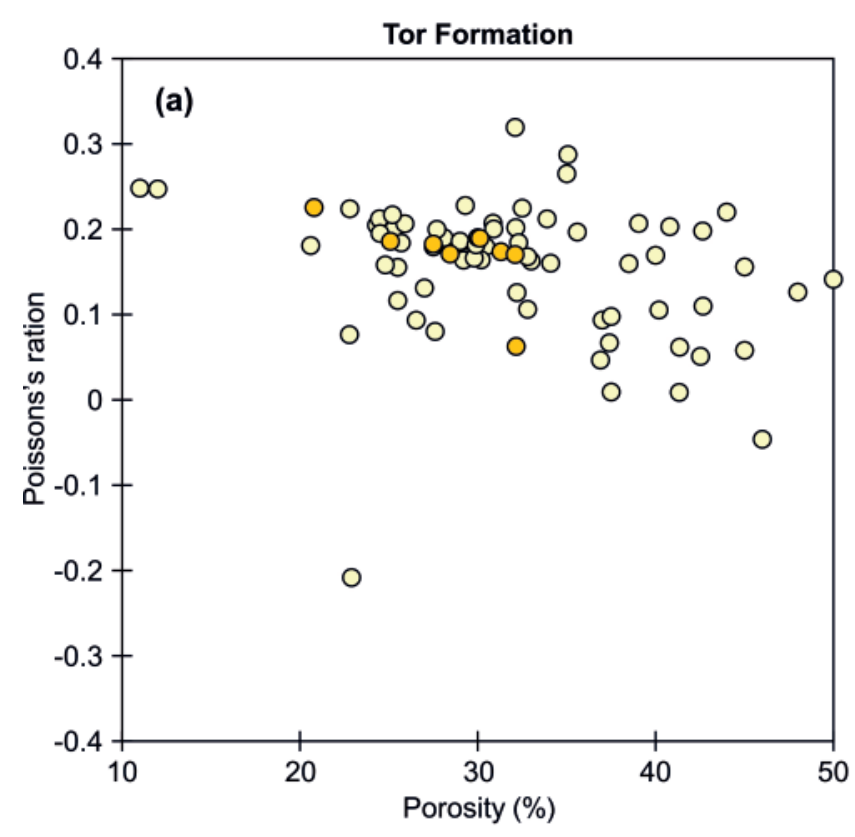

Poisson
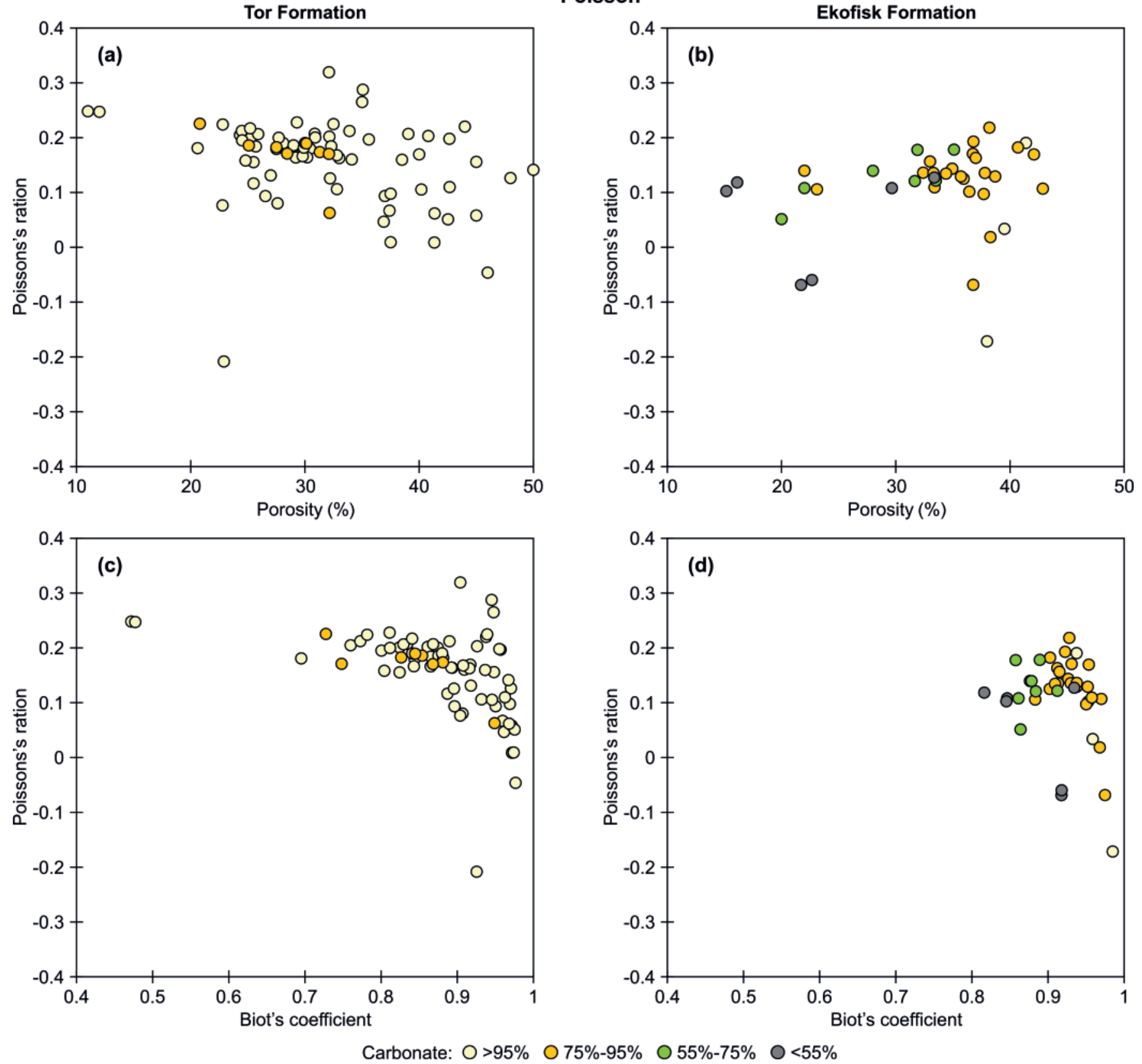

Fig. 17. Poisson's ratio (a, b) vs. porosity; $(\mathbf{c}, \mathbf{d})$ vs. Biot's coefficient. The data points are annotated with respect to carbonate content. For the relatively carbonate-rich Tor Formation samples, Poisson's ratio is related negatively to porosity and Biot's coefficient and thus seems to be related positively to degree of cementation. The more impure Ekofisk Formation samples are less cemented, and high silicate content results in low porosity, high Biot's coefficient and relatively low Poisson's ratio.

Diagenetic processes and porosity

Cementation of chalk should affect $\delta^{18} \mathrm{O}$ and Biot's coefficient and, when these two properties are compared with porosity, a more or less distinct pattern with respect to formation and field is found (Figs 13, 14). For the Tor Formation, most samples from the Dan and Ekofisk fields follow a trend where porosity decline is associated with a relatively steep decline in $\alpha$ (Fig. 13). This is probably a consequence of pore-filling cementation (Figs 5, 9). For $\delta^{18} \mathrm{O}$ no clear porosity trend is seen (Fig. 14), probably because no clear porosity-depth trend is seen (Fig. 2), as a reflection of partial primary depositional control on porosity.

The South Arne samples fall on a relatively low $a-\phi$ trend (Fig. 13). This is an indication of pore-stiffening cementation with a relatively high element of porosity-preserving recrystallization. The recrystallization of the (relatively shallow) high porosity mudstones has taken place at relatively low water saturation, as indicated by a relatively high $\delta^{18} \mathrm{O}$ (Figs 2, 14). For the remaining South Arne samples no clear $\delta^{18} \mathrm{O}$-porosity trend or texture-effect is seen and $\delta^{18} \mathrm{O}$ is lower, probably a reflection of pore-filling cementation at high water saturation (Fig. 14).

The Tor Formation samples of Valhall fall in two groups: one group of porous chalk with an $a$ of $c .0 .95$, and two cemented (possibly Hod Formation) samples with an $a$ below 0.5 (Fig. 13). Valhall samples have high $\delta^{18} \mathrm{O}$ irrespective of porosity, an indication of isotope equilibration with porewater at low water saturation (Fig. 14) and, accordingly, Valhall samples have a relatively low $a$ for a given porosity, 


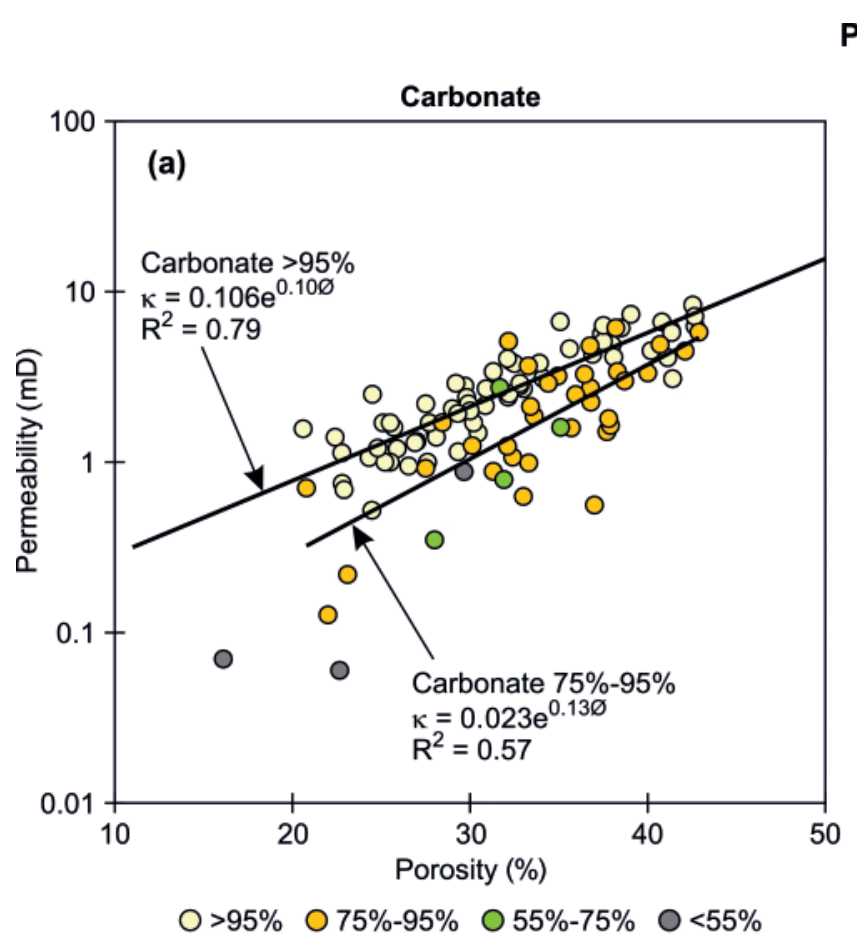

\section{Poro - perm \\ All data}

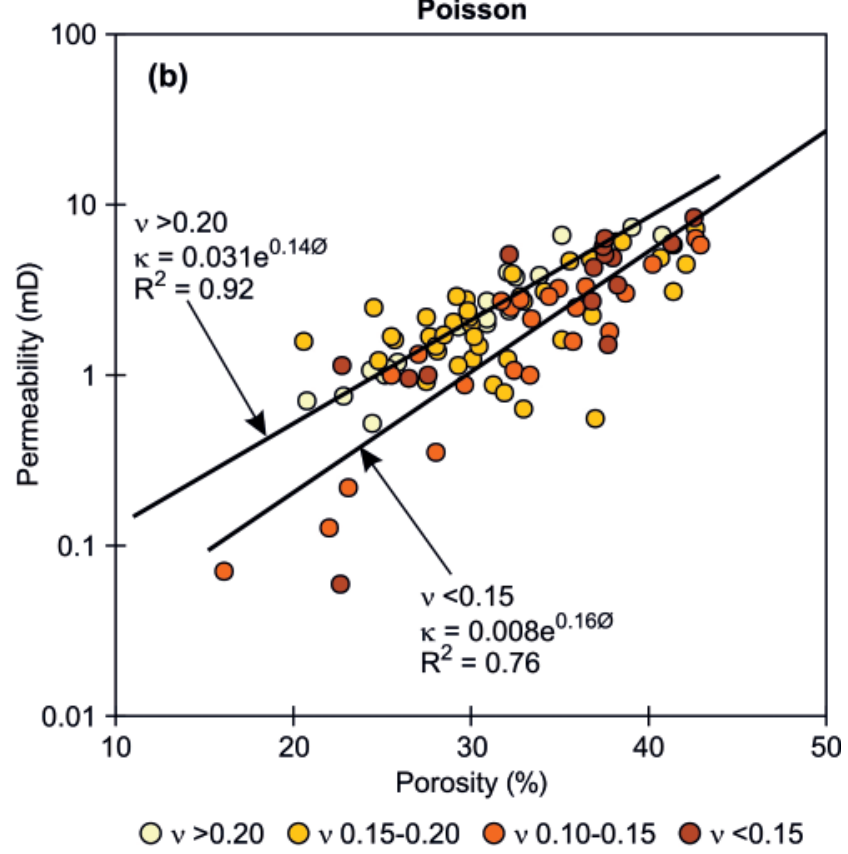

Fig. 18. Permeability, $\kappa$, versus porosity, $\varnothing$, for all samples: (a) annotated with respect to carbonate content; (b) annotated with respect to Poisson's ratio, $v$. Significant relationships may be found for the following groups: carbonate $>95 \%$ (66 samples), carbonate $75-95 \%$ ( 34 samples), $v>0.2$ (19 samples) and $v<0.15$ (39 samples). For samples with low carbonate content and intermediate $v$, the scatter is too large to obtain a useful relationship.

indicating stiff grain contacts and a relatively high element of porosity-preserving recrystallization (Fig. 13).

In the Ekofisk Formation, samples with mudstone microtexture tend to have relatively high $\delta^{18} \mathrm{O}$ and Biot's coefficient, whereas samples with packstone texture tend to have relatively low $\delta^{18} \mathrm{O}$ and Biot's coefficient (Figs 13, 14). This is probably a consequence of preferred cementation of microfossils. A cementation focused in microfossils is also indicated by a relatively modest decrease in $a$ with decreasing porosity (Fig. 13). The Tyra Field samples fall on a trend of relatively high $\delta^{18} \mathrm{O}$ and relatively low $\alpha$. This may indicate recrystallization at relatively low water saturation where available porewater is limited and cementation primarily porosity-preserving, leading to a relatively low $a$ for a given porosity.

\section{Textural control on permeability and capillary entry} pressure

Whereas depositional texture has some control on porosity, it has only little control on the relationship between porosity and permeability (Fig. 15). For the Tor Formation, samples from the Dan and Ekofisk fields fall along one trend, whereas samples from the South Arne Field tend to have a lower permeability for a given porosity (Fig. 15). For the Ekofisk Formation, samples from the Ekofisk Field fall on a trend comparable with the Tor Formation samples from South Arne, whereas the Tyra Field samples tend to have a lower permeability for a given porosity (Fig. 15). In accordance with Maliva \& Dickson (1992), the porosity-permeability trends are probably controlled by the content of silicates. The porositypermeability trends vary among fields and formations, probably as a consequence of stratigraphic and regional variations in quartz content and clay type because gas-permeability for a given porosity is controlled directly by specific surface (Røgen \& Fabricius 2002).
Capillary entry pressure of chalk is predictable from porosity and specific surface only for chalk that is homogeneous on a micro-scale (Røgen \& Fabricius 2002) and, accordingly, relatively heterogeneous textures tend to have lower capillary entry pressure for a given porosity (Fig. 16).

Prediction of permeability and capillary entry pressure from porosity and Poisson's ratio of dry samples

According to expectations, Poisson's ratio, $v$, should be related to carbonate content and pore stiffness. The Tor Formation samples have high carbonate content and $v$ accordingly tends to increase as porosity and Biot's coefficient decreases and pores stiffen (Fig. 17). The Ekofisk Formation samples have variable carbonate content and, as compared with the Tor Formation samples, Ekofisk Formation $v$ tends to be relatively low for low porosities and Biot's coefficient tends to be relatively high, as a reflection of the porosity-reducing and pore-softening effect of silicates (Fig. 17). In both formations, $v$ may thus be related negatively to specific surface with respect to bulk volume. The reason is that in a pure carbonate lithology, specific surface with respect to bulk volume will decrease as pores stiffen; whereas in impure chalk, specific surface with respect to bulk volume will decrease as content of fine-grained silicates decreases.

Carbonate content or Poisson's ratio may help in predicting permeability and capillary entry pressure from porosity if the locality and formation of the chalk is unknown or poorly studied (Figs 18, 19). For permeability, significant relationships were found for the following groups: carbonate $>95 \%$ and carbonate $75-95 \%$. For samples with low carbonate content the scatter is too great to obtain a useful relationship (Fig. 18). Significant relationships were also found for $v>0.2$ and $v<0.15$. For samples with intermediate $v$, the scatter is too large to obtain a useful relationship (Fig. 18). For prediction of capillary 

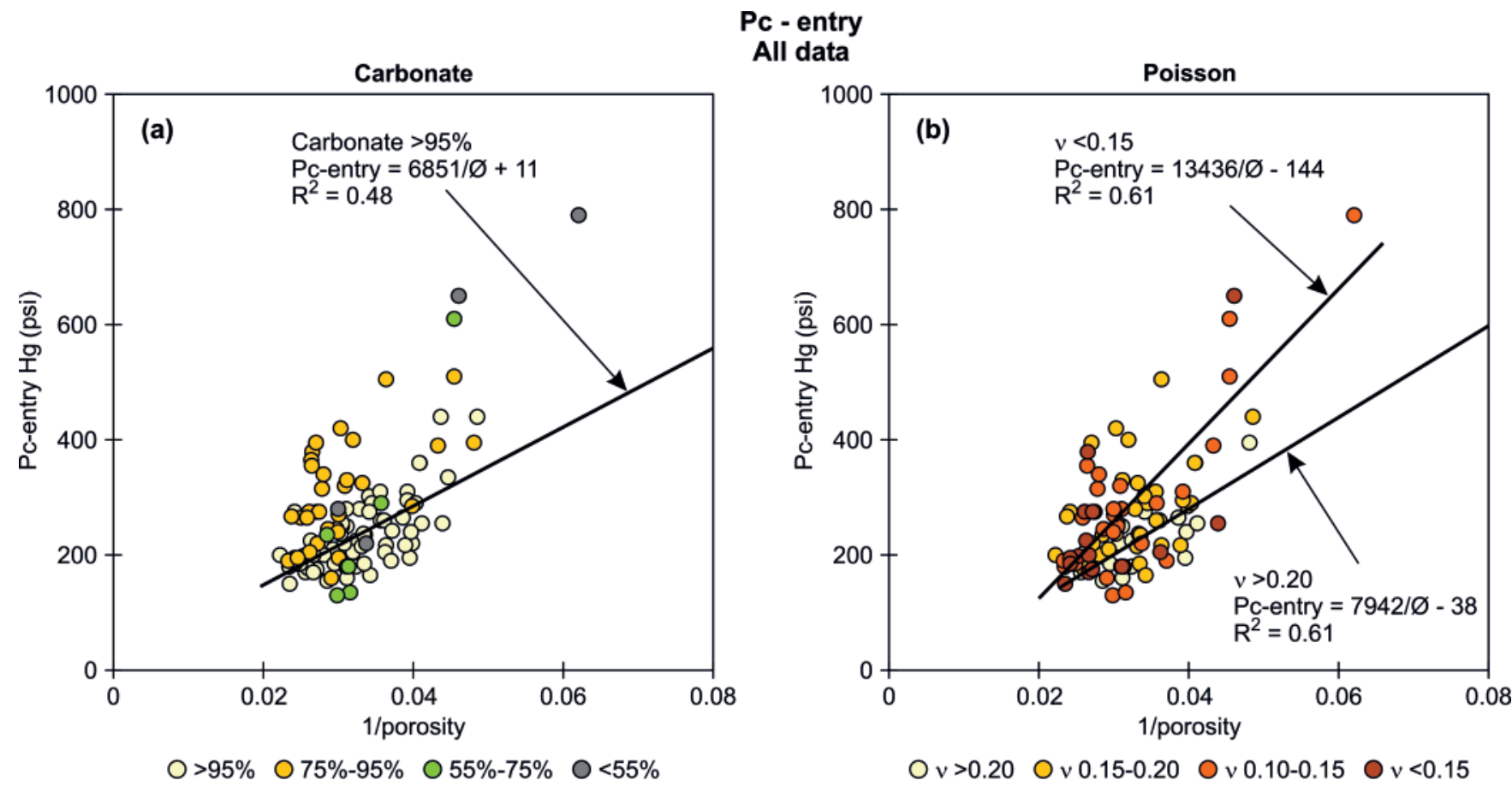

Fig. 19. Air-mercury capillary entry pressure versus inverse porosity, $1 / \varnothing$, for all samples: (a) annotated with respect to carbonate content (refer to Fig. 18); (b) annotated with respect to Poisson's ratio, $v$ (refer to Fig. 18). Significant relationships may be found for the following groups: carbonate $>95 \%$ (64 samples), $v>0.2$ (17 samples) and $v<0.15$ (41 samples).

entry pressure, significant relationships were found for the following groups: carbonate $>95 \%, v>0.2$ and $v<0.15$ (Fig. 19).

\section{CONCLUSIONS}

Depositional texture influences porosity: the most porous samples tend to have mudstone microtexture. Clast-bearing samples may have high or low porosity. Wackestone microtexture is frequent for intermediate porosities, whereas packstones and clay-bearing chalk tend to have low porosity.

We do not find a relationship between high porosity and re-deposition of chalk.

Textural control on porosity varies among the fields. In some fields primary texture is the primary control on porosity. In other fields porosity is primarily controlled by diagenesis as quantified by $\delta^{18} \mathrm{O}$ and Biot's coefficient.

Porosity in Tor Formation of the Dan and South Arne fields seems primarily to be controlled by pore-filling cementation, whereas content of microfossils gives a second order porosity reducing effect. In contrast, porosity in the Tor Formation of the Valhall field and Ekofisk Formation of Tyra and Ekofisk fields seems primarily to be controlled by the sorting of the fine-grained mud-matrix, whereas the second order control is content of microfossils. Finally, in the Tor Formation of the Ekofisk field porosity seems primarily to be controlled by the sorting of the fine-grained mud-matrix, whereas the second order effect is pore-filling cementation.

Closed system diagenesis is indicated by a positive correlation of $\delta^{13} \mathrm{C}$ and $\delta^{18} \mathrm{O}$, and a relatively large change in $\delta^{18} \mathrm{O}$ corresponding to a smaller change in $\delta^{13} \mathrm{C}$ in the Dan, Tyra, South Arne, and Ekofisk fields in accordance with Jørgensen (1987).

Isotope data indicate that cementation in Dan and probably also Ekofisk fields has taken place at high water saturation, whereas cementation in Valhall field, parts of the South Arne and possibly also Tyra field has taken place at low water saturation, probably as a consequence of introduction of hydrocarbons at relatively low burial.

Whereas depositional texture has some control on porosity, it has little control on the relationship between porosity and permeability.

Relatively heterogeneous lithotypes and textures tend to have low capillary entry pressure for a given porosity as compared to more sorted textures.

Carbonate content or Poisson's ratio may help in predicting permeability and capillary entry pressure from porosity.

This paper presents results from the Joint Chalk Research programme phase V. Project leaders were A. Mortensgaard and M. Reppert. Joint Chalk Research is thanked for encouragement and data. The paper also includes data from a project sponsored by Danish Energy Research Program EFP-98. Acoustic measurements were carried out at NTNU under the supervision of R. Holt. Further thanks are due to K. Carlsen, H. Diaz, F. Kragh and S. H. Nguven for technical support, and to M. Borre and J. M. Hvid for discussions.

\section{REFERENCES}

Andersen, M.A. 1995. Petroleum Research in Chalk. Joint Chalk Research Phase IV. Rogaland Research, Stavanger, Norway. [For access to all following JCR reports, please contact the Norwegian Petroleum Directorate, Professor Olav Hanssens vei 10, Postboks 600, N-4003 Stavanger, Norway.].

Brasher, J.E. \& Vagle, K.R. 1996. Influence of lithofacies and diagenesis on Norwegian North Sea chalk reservoirs. American Association of Petroleum Geologists Bulletin, 80, 746-769.

Brewster, J., Dangerfield, J. \& Farrell, H. 1986. The geology and geophysics of the Ekofisk field waterflood. Marine and Petroleum Geology, 3, 139-169.

Brunauer, S., Emmett, P.H. \& Teller, E. 1938. Adsorption of gases in multimolecular layers. Journal of the American Chemical Society, 60, 309-319.

Caillet, G., Judge, N.C., Bramwell, N.P., Meciani, L., Green, M. \& Adam, P. 1997. Overpressure and hydrocarbon trapping in the Chalk of the Norwegian Central Graben. Petroleum Geoscience, 3, 33-42. 
Crabtree, B., Fritsen, A., Mandzuich, K. et al. (eds) 1996. Description and Classification of Chalks North Sea Central Graben. Joint Chalk Research Phase IV.

Damholt, T. \& Surlyk, F. 2004. Laminated-bioturbated cycles in Maastrichtian chalk of the North Sea: oxygenation fluctuations within the Milankovitch frequency band. Sedimentology, 51, 1323-1342.

Doyle, C. \& Conlin, J.M. 1990. The Tyra Field. In: Buller, A.T. et al. (eds) North Sea Oil and Gas Reservoirs-II. The Norwegian Institute of Technology, Graham \& Trotman, London, 47-65.

Dunham, R.J. 1962. Classification of carbonate rocks according to depositional texture. In: Ham, W.E. (ed.) Classification of Carbonate Rocks. American Association of Petroleum Geologists Memoir, 1, 108-123.

Engstrøm, F. 1995. A new method to normalize capillary pressure curves. Paper presented at the International Symposium of the Society of Core Analysts, California, USA.

Fabricius, I.L. 2003. How burial diagenesis of chalk sediments controls sonic velocity and porosity. American Association of Petroleum Geologists Bulletin, 87, 1755-1778.

Fabricius, I.L. \& Borre, M.K. 2007. Stylolites, porosity, depositional texture, and silicates in chalk facies sediments, Ontong Java Plateau - Gorm and Tyra fields, North Sea. Sedimentology doi: 10.1111/j.1365-3091.2006.00828.x.

Farmer, C.L. \& Barkved, O.I. 1999. Influence of syn-depositional faulting on thickness variations in chalk reservoirs - Valhall and Hod fields. In: Fleet, A.J. \& Boldy, S.A.R. (eds) Petroleum Geology of Northwest Europe: Proceedings of the 5th Conference. Geological Society, London, 949-957.

Gassmann, F. 1951. Über die Elastizität poröser Medien. Vierteljahrsschrift der Naturforschenden Gesellschaft in Zürich, 96, 1-23.

Gommesen, L., Fabricius, I.L., Mukerji, T., Mavko, G. \& Pedersen, J.M. 2007. Elastic behaviour of North Sea chalk: A well log study. Geophysical Prospecting (in press).

Hatton, I.R. 1986. Geometry of allochthonous Chalk Group members, Central Trough, North Sea. Marine and Petroleum Geology, 3, 79-98.

Hoefs, J. 2004. Stable Isotope Geochemistry. Springer, Berlin.

Japsen, P. 1998. Regional velocity-depth anomalies, North Sea Chalk: a record of overpressure and Neogene uplift and erosion. American Association of Petroleum Geologists Bulletin, 82, 2031-2074.

Jensenius, J. \& Munksgaard, N.C. 1989. Large scale hot water migration systems around salt diapers in the Danish Central Trough and their impact on diagenesis of chalk reservoirs. Geochimica et Cosmochimica Acta, 53, 79-88.

Jørgensen, N.O. 1987. Oxygen and carbon isotope composition of Upper Cretaceous chalk from Danish sub-basin and the North Sea Central Graben. Sedimentology, 34, 559-570.

Kennedy, W.J. 1980. Aspects of chalk sedimentation in the southern Norwegian offshore. The Sedimentation of the North Sea Reservoir Rocks. Geilo, 11-14 May. Norwegian Petroleum Society, Oslo.

Kennedy, W.J. 1987. Sedimentology of Late Cretaceous/Paleocene chalk reservoirs, North Sea Central Graben. In: Brooks, J. \& Glennie, K. (eds) Petroleum Geology of North West Europe. Graham \& Trotman, London, 469-481.

Klinkenberg, L.J. 1941. The Permeability of Porous Media to Liquids and Gases. Drilling and Production Practice. API, New York.

Kozeny, J. 1927. Uber Kapillare Leitung des Wassers in Boden. Sitzungsberichte der Akadamie der Wissenschaften in Wien, 136, 271-306.

Kristensen, L., Dons, T., Maver, K.G. \& Schiøler, P. 1995. A multidisciplinary approach to reservoir subdivision of the Maastrichtian chalk in the Dan field, Danish North Sea. American Association of Petroleum Geologists Bulletin, 79, 1650-1660.
Leverett, M.C. 1940. Capillary behavior in porous solids. Journal of Petroleum Technology, August, 1-17.

Lind, I. \& Grøn, P. 1996. Porosity variation in chalk. Zentralblatt für Geologie und Paläontologie, 1994, 763-772.

Mackertich, D.S. \& Goulding, D.R.G. 1999. Exploration and appraisal of the South Arne Field, Danish North Sea. In: Fleet, A.J. \& Boldy, S.A.R. (eds) Petroleum Geology of Northwest Europe: Proceedings of the 5 th Conference. Geological Society, London, 959-974.

Maliva, R.G. \& Dickson, J.A.D. 1992. Microfacies and diagenetic controls of porosity in Cretaceous/Tertiary chalks, Eldfisk Field, Norwegian North Sea. American Association of Petroleum Geologists Bulletin, 76, 1825-1838.

Maliva, R.G., Dickson, J.A.D. \& Råheim, A. 1991. Modelling of chalk diagenesis (Eldfisk Field, Norwegian North Sea) using whole rock and laser ablation stable isotopic data. Geological Magazine, 128, 43-49.

Mavko, G., Mukerji, T. \& Dvorkin, J. 1998. The Rock Physics Handbook. Cambridge University Press, Cambridge.

Megson, J. \& Hardman, R. 2001. Exploration for and development of hydrocarbons in the Chalk of the North Sea: a low permeability system. Petroleum Geoscience, 7, 3-12.

Mortensen, J., Engstrøm, F. \& Lind, I. 1998. The relation among porosity, permeability, and specific surface of chalk from the Gorm field, Danish North Sea. Paper SPE 31062. SPE Reservoir Evaluation \& Engineering, 1, 245-251.

Perch-Nielsen, K. 1979. Calcareous nannofossil zonation at the Cretaceous/ Tertiary boundary in Denmark. In: Birkelund, T. \& Bromley, R.G. (eds) Cretaceous-Tertiary Boundary Events Symposium. University of Copenhagen, Copenhagen, 115-135.

Røgen, B. \& Fabricius, I.L. 2002. Influence of clay and silica on permeability and capillary entry pressure of chalk reservoirs in the North Sea. Petroleum Geoscience, 8, 287-293.

Røgen, B., Gommesen, L. \& Fabricius, I.L. 1999. Chalk Rock Catalogue. Joint Chalk Research Phase V.

Røgen, B., Gommesen, L. \& Fabricius, I.L. 2001. Grain size distributions of Chalk from Image analysis of Electron Micrographs. Computers \& Geosciences, 27, 1071-1080.

Røgen, B., Fabricius, I.L., Japsen, P., Høier, C., Mavko, G. \& Pedersen, J.M. 2005. Ultrasonic velocities of North Sea chalk samples - influence of porosity, fluid content and texture. Geophysical Prospecting, 53, 481-496.

Scholle, P.A. \& Arthur, M.A. 1980. Carbon isotope fluctuations in Cretaceous pelagic limestones: potential stratigraphic and petroleum exploration tool. American Association of Petroleum Geologists Bulletin, 64, 67-87.

Scholle, P.A., Albrechtsen, T. \& Tirsgaard, H. 1998. Formation and diagenesis of bedding cycles in uppermost Cretaceous chalks of the Dan Field, Danish North Sea. Sedimentology, 45, 223-243.

Taylor, S.R. \& Lapré, J.F. 1987. North Sea chalk diagenesis: its effect on reservoir location and properties. In: Brooks, J. \& Glennie, K. (eds) Petroleum Geology of North West Europe. Graham \& Trotman, London, 483-495.

Vejbæk, O.V., Rasmussen, R., Japsen, P., Bruun, A., Pedersen, J.M., Marsden, G. \& Fabricius, I.L. 2005. Modeling seismic response from North Sea chalk reservoirs resulting from changes in burial depth and fluid saturation. In: Doré, A.G. \& Vining, B.A. (eds) Petroleum Geology: North-West Europe and Global Perspectives -Proceedings of the 6th Conference. Geological Society, London, 1401-1413.

Ziegler, P.A. 1990. Geological Atlas of Western and Central Europe 2nd edn. Shell Internationaal Petroleum Maatschaapij B.V, The Hague. 